BUREAU OF ECONOMIC GEOLOGY

The University of Texas

Austin 12, Texas

JOHN T. LONSDALE, Director

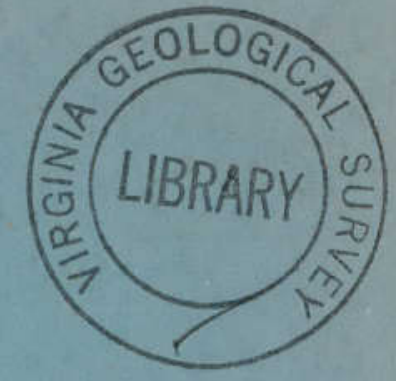

Report of Investigations-No. 11

\title{
Correlation Between Surface and Subsurface Sections of the Ellenburger Group of Texas
}

\author{
By \\ LEO HENDRICKS
}

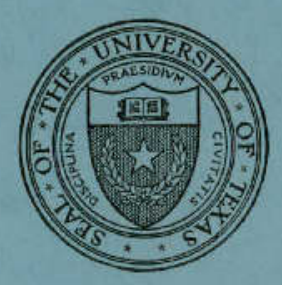

July 1952 


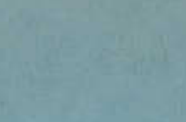

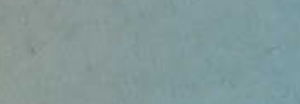

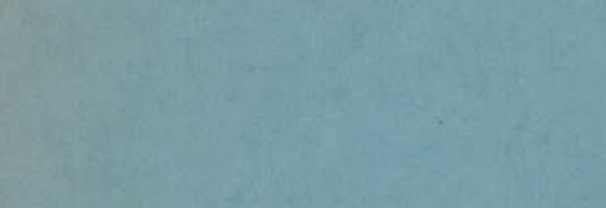

forthing 90

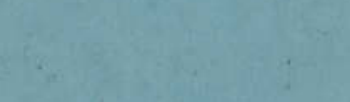

$x_{x \rightarrow 4}=4 x^{2} x^{2}$

$3 x^{3}$

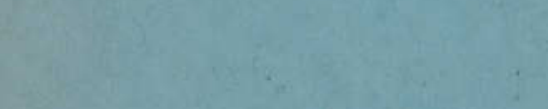

$\sin ^{2} \sin ^{2}$

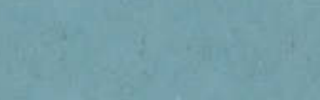

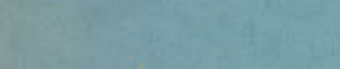

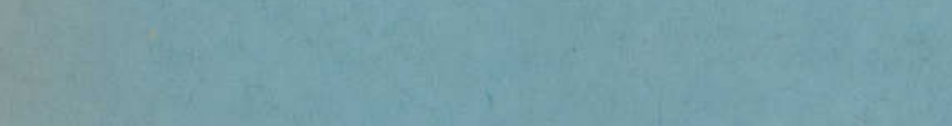

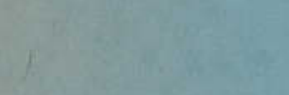


BUREAU OF ECONOMIC GEOLOGY

The University of Texas

Austin 12, Texas

JOHN T. LONSDALE, Director

Report of Investigations-No. 11

\section{Correlation Between Surface and Subsurface Sections of the Ellenburger Group of Texas}

By

\section{LEO HENDRICKS}

July 1952 


\section{CONTENTS}

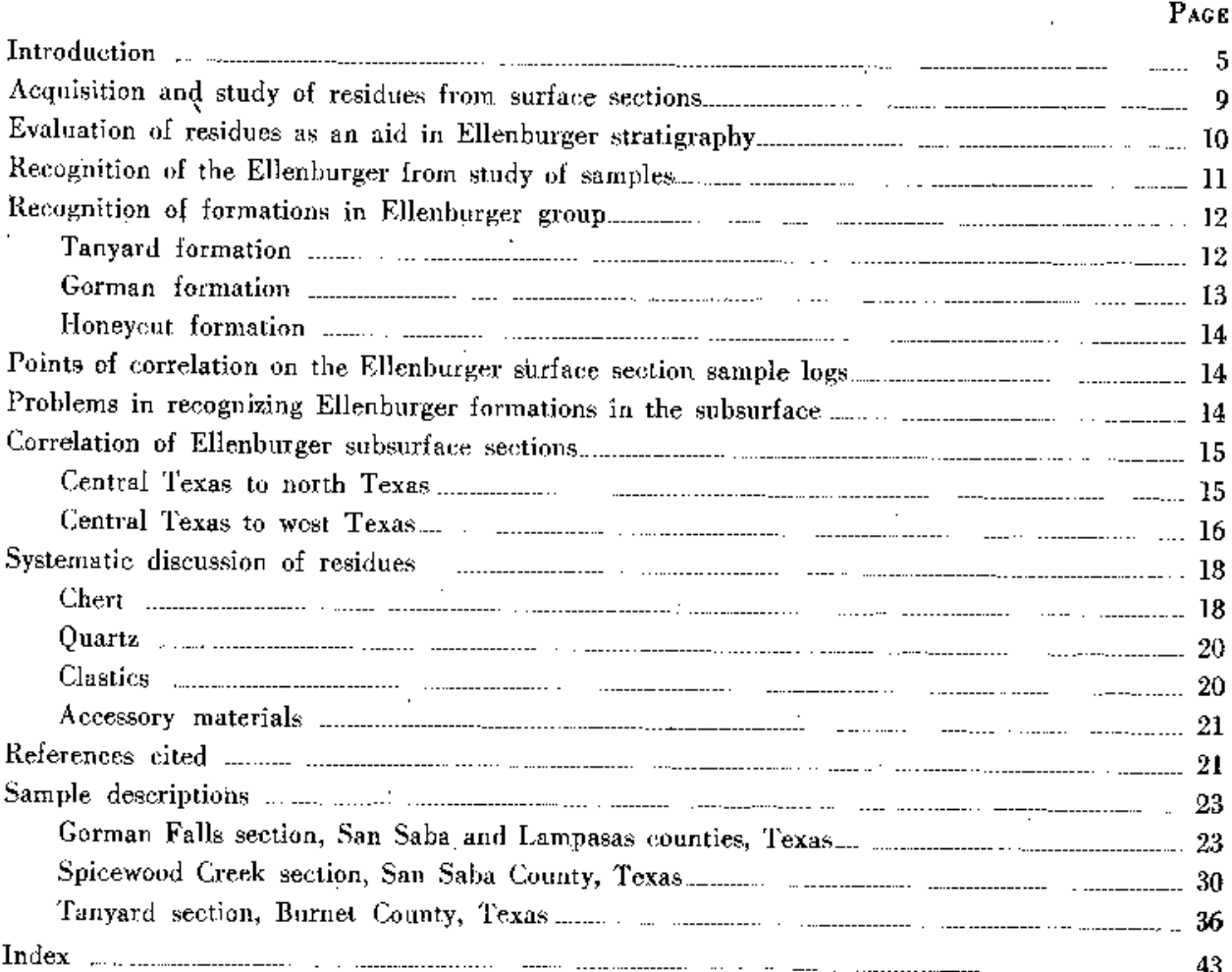

\section{ILLUSTRATIONS}

Figine-

1. County outline map showing approximate extent of kllenburger in 'Texas PtATES. . (in pocket)

I. Index map of Llano uplift showing area where Ellenburger has been mapped in detail by Clond and Barnes.

II. Correlation of Ellenburger sections in central Texas,

IIl. Correlation of Ellenburger sections from central to north Texas.

IV. Correlation of Ellenburger sections across north-central Texas.

V. Correlation of Ellenburger sections Irom central to west Texas.

VI. Regional correlation of the Ellenburger group (from Cloud and Barnes, 1946).

TABLES-

1. Thicknesses of units of the Ellenburger group (Lower Ordovician) as measured in various parts of the Llano up]ift.

2. Genetic classification of residues. 
, 


\section{CORRELATION BETWEEN SLRFACE AND SUBSURFACE SECTIONS OF THE ELLENBLRGER GROUP OF TEXAS}

\section{Leo Hendricks}

\section{INTRODUCTION}

The Ellenburger of Texas was first de- into several formations and the term Elfined as a marine limestone formation of lenburger given group status (Cloud and Cambrian and Ordovician age (Paige, Barnes, 1948). The group forms an im1912), but recently it has been subdivided portant unit in the geology of Texas, its

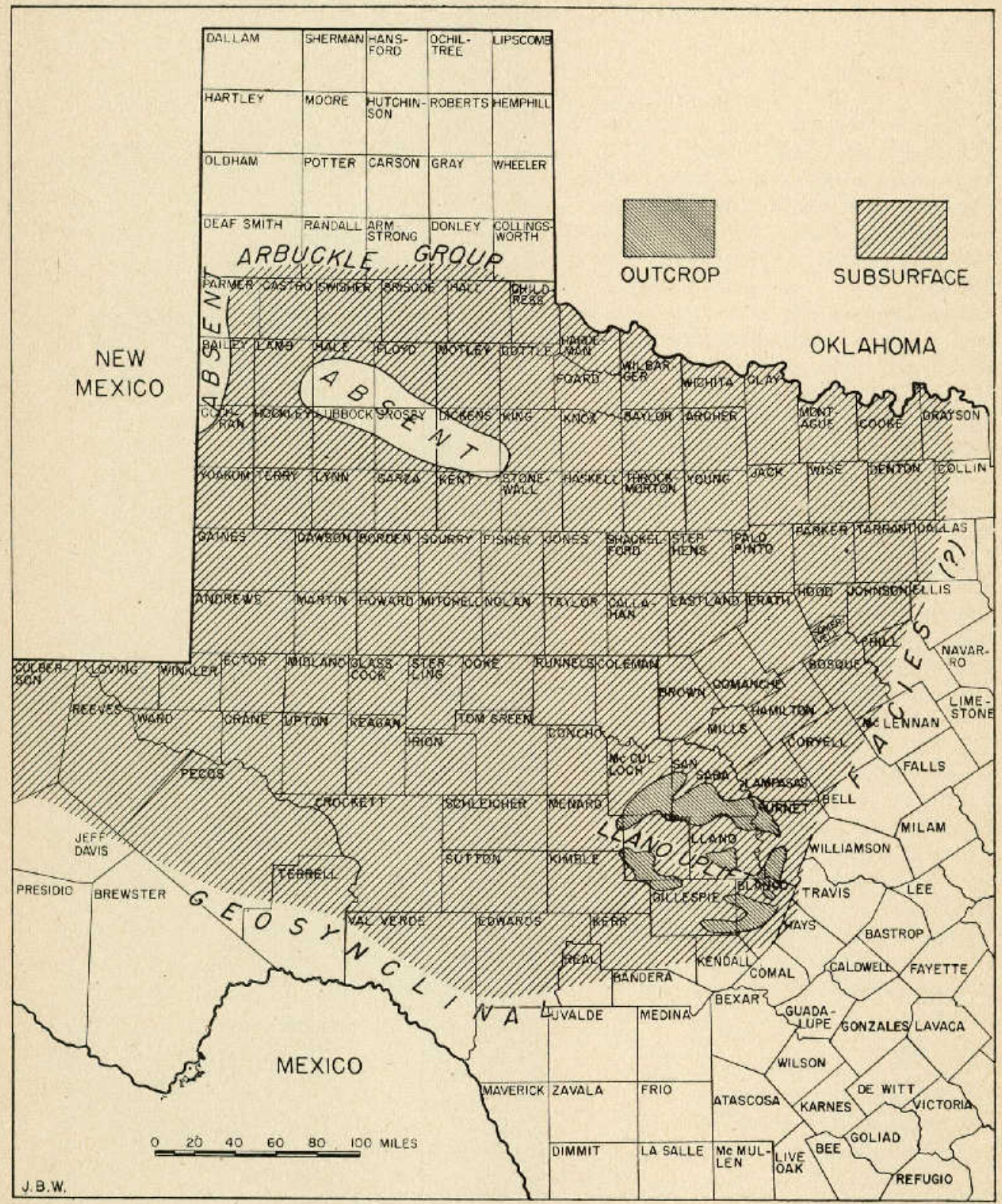

Fig. 1. County outline map showing approximate extent of Ellenburger in Texas. 
known extent in both surface and subsurface covering approximately one-half of the State (fig. 1). Consequently the Ellenburger has received the attention of many geologists over a period of more than forty years. The greatest amount of information concerning the Ellenburger has come from wells drilled in exploration for oil and gas. This information from the subsurface is the basis for present concepts of the lateral extent and regional changes in thickness and lithologic character of the group (Sellards, 1933b). The top of the group serves as an important key horizon for mapping structure in the subsurface of large parts of north, central, and southwest Texas (Sellards and Hendricks, 1946). Data from well samples and cores have been used to make qualitative subdivisions and correlations within the formation (Cole. 1942, p. 1398; Crowley and Hendricks, 1945 , p. 413). No paleontological correlations are possible from well data because well samples and cores from the Ellenburger are practically barren of fossils.

Use of the term "Ellenburger" has some geographical as well as geological limitations. Rocks in the subsurface of northern Texas referred to as Ellenburger are identical with rocks in the subsurface of southern Oklahoma referred to the Arbuckle group (Decker, 1939). The two groups exhibit recognizable differences in their respective type areas, but the gradation from one to the other is so gradual that no welldefined transition zone can be recognized. Both the Arbuckle and the Ellenburger are assumed to lose their identity eastward in a geosynclinal clastic facies of Ordovician rocks (Sellards, 1938). Southward the Ellenburger possibly grades in part into the limestone formation of Lower Ordovician age recognized in the Marathon uplift as the Marathon formation (King, 1937). Westward a portion of the Ellenburger probably grades into the Lower Ordovician El Paso limestone (Richardson, 1909). Northwestward the group in part may grade into the Manitou formation of Colorado (Brainerd, B a ld wi n, and Keyte, 1933). Thus the rocks referred to as Ellenburger are largely a facies unit deposited in a great epicontinental sea.

The best evidence for stratigraphic correlation of the group has come from field study and interpretation of faunal evidence from the outcrop. Dake and Bridge

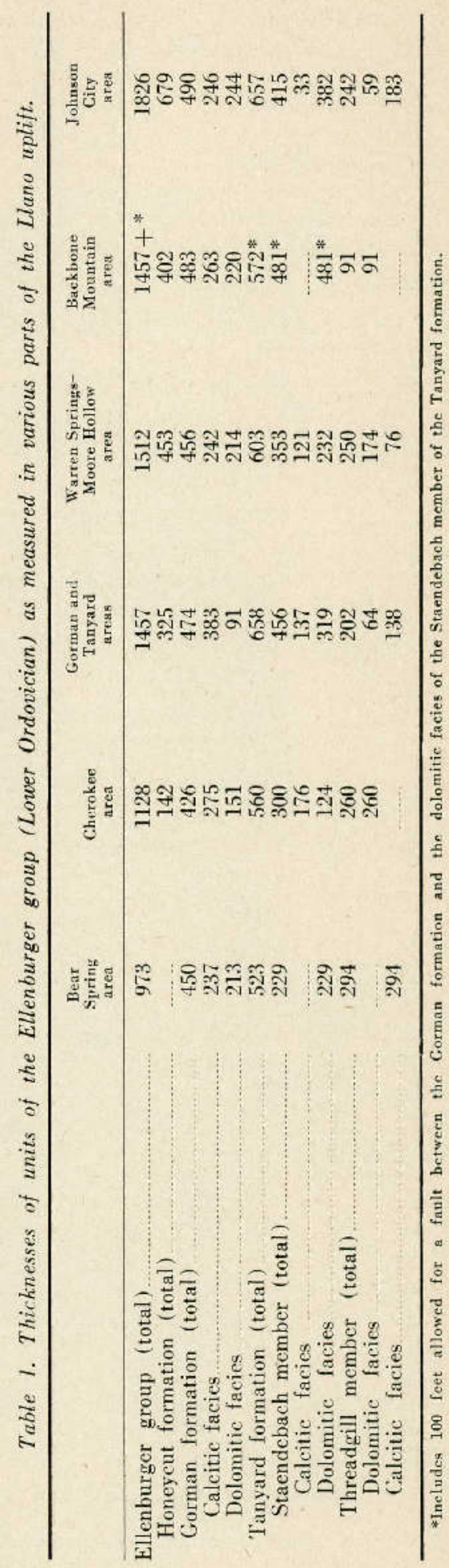


(1932) recognized several faunal zones of Cambrian and Ordovician age in the beds mapped as Eillenburger. In a recent cooperative project V. E. Barnes, of the Bureau of ]iconomic Geology of The University of Texas, and P. E. Cloud, Jr., of the U. S. Geological Survey, (Cloud and Barnes, 1948) mapped portions of the Fllenburger outerop in detail in the Llano uplift of Texas (Pl. I). A summary of their major concepts concerning the group follows.

The Ellenburger group is now limiled to heds of Lower Ordovician age.

The Ellenburger is known to be present at the surface onTy in the Llano uplift region of central Texas, also known as the Central Mineral region. The group was studied and mapped in detail, and complete scctions were measured in cight areas within the Llano uplift region (Pl. I). Reconnaissance studies were nade throughout much of the oulcrop area of the group, which surrounds and hies partly within the large topographic basin at the center of the IJano uplift. Three formations can be recognized as making up the group in the area of its outcrop.

The l'anyard, the oldest formation, is an inconsistent series of limostone and dolomite beds that averages $5 \%$ feet thick" in seven measured sections. Changes in thickness are due chiefly to thitning from east to west. The limestones and dolomites characteristically have very abrupt lateral gradation from one to the other. Two mombers are remonnized within the formation.

The Threadgrill, lower member of the Tanyard, is predominantly dolomite but may he partly or all limestone, depending on facies. The nember is essentially nonglauconitic, nonarenaccous, and without silt in the eastern side of the region, but silt is present in it on the western side. The member averages 234 feet thick in eight sections moasured. Some bases for recognition in the field are diagnostic fossils, coarseness of grain ot dolomite beds, typically nonporcelarteous chert.

The Standebach, upper inember of the Tan. yard, generally is made up of a lower dolomite unit and an upper limestone unit but in places is all dolomite. 'The member gveruges 359 feet thick in. scven sections measured. Field recognition is based largely on intermediate and fine grain size of the dolomite, the typitally porcelaneous chert, and diagnostic fossils.

The Gorman formation lies on the Tanyard with some slight evidence of local disconformity. The formalion consists generally of a Tower unit of microgranular dolomite and an upper unit of limestone with dolomite occurring in the middle of this upper unit. The formation averages 463 fect thick in six sections measured wherc crosion had romoved little or none of the rocks betore later deposition. Recognition of the formation is bascd on diugnostic fossils, the usually very fine grain of the dolonites, the typically chalcedonic to porcelaneous chert, and the presence of sand grains oceurriny in zones.

The Honeycut folmation, lying conformably on the Golman, consists in its fullest known develop- ment of a lower unit of alternating limestone and dolomite, a middle urrit of dolomite, and an upper unit of limestone. The dolomitcs are gen. erally mimogranular, and the cherts are chalce. donic: to porcelancous. Recognition dejends or diagnostic fossils, senerally lighter color of the dolomites, absence of sand except in the lower 50 feet. The formation was entirely removed by erosion belure later deposition in the western half of the outcrop area, and it was differentially eroded over the rcmainder of the area. Thus no definitive upper limit can be placed on the formation from surface study. Its greatest known thickness at the surface is 679 fect.

Field evidence and succession of faumas indicate that deposition was almost if not entirely, continuous from time of deposition of the oldest to the youngest rocks in the Ellenburger group. Conglomerate at one locality and a slight irregularity of contact at another judicate a possible break in sedimentation between the Tanyard and the Gorman. Sediments apparentiy were rather pure, chemically precipitated, lime muds that hecame limestone or dolomite under diagenetic processes. The Ellenburger in the area of its outcrop is renarkahly frce of terrigenous material, sand in the Gorman formation being. the must notable exception. The bulk of the evidence indicates that deposition oceurred in a large, shallow-water area separated from land to the soutl and east by a deep trough, or by persistent currents that successtully withheld watcr-borne terrigenous material. Changes in faunal make-up from one level to another possibly were due to regional. changes in ocean depth, salinity, temperature, or other conditions afferting life in the sea.

The Ellenlurger lics with apparent conformity on the U Uper Cambrian in the western part of the Llano uplift region, but irregularity of contact indicates it may be mconformable with the Upper Cambrian in the eastern part of the region. Throughout the Llano resion the Ellenburger has a compound unconformity at its top, having been reached by erosion int some or all of its extent by at least eight cycles of erosion, each followed by overlapping deposition. Differential erosion has brought about a thinning of the Ellenburger westward across the area of its outerop (T'able 1 , j. 6). Devonian and younger formations rest on successively older Eilenburger beds from east to west. The Honeycunt formation has all been removed west of the longitude of western San Saba County.

The Ellenturger contains beds of earliest Ordovician age, being apparently conformable, in at least a part of its octurrence, with Upper Cambrian. The group does not contain beds equivalent to youngest Lower Ordovician in its outcrop area. Jower Ordovinian beds younger than EIlenburger are present at the surface in the Marathon, Van Horn, and El Paso regions of west Texas, in the Wichita and Arbickle Mountains of Oklahoma, and in the Ozark region of Missouri and Arkansas. Regional correlation with these areas is shown. on Plate VI.

The above summary presents briefly the nature and stratigraphic significance of the Ellenburger as now defined in the area of 
its outcrop. In its subsurface occurrence the Ellenburger has been defined as including beds up to the base of the Simpson formation of Middle Ordovician age (Sellards, 1933a). Thus the Fillenburger in a porlion of its occurrence may contain some beds younger than any occurring in the Honeycut formation in its thickest development. The youngest known beds assigned to the Honeycut formation are overlain by rocks of Devonian age. It seems most likely that the hiatus of the uneonformity includes beds present underncath Middle Ordovician in west and north Texas. Whether those Lower Ordovician beds younger than Honeycut as defined should be included in the Honeycut becomes a matter of judgment based on evidence from many sections. Especially, subsurface sections of north Texas should be compared wilh sampled sections of lower Ordovician rocks present in the Arbuckle and Wichita Mountains of Oklahoma.

An understanding of the occurrence of the Ellenburger formations in the subsurface involves: the use of depcndable correlative criteria common to both outcrop and subsurface data. Since faunal evidence obtained so far in well data is too rare to be of use, the physical or qualitative characteristics of the Ellenburger subdivisions offer the only recourse for correlative data to be found in both outcrop and well samples. The major lithologic characteristics may serve to distinguish the group as a whole from other rocks but do not offer evidence for widespread correlation wilhin the group. Cloud and Barnes found thal grain size in the dolomites was a gencral guide for recognizing some subdivisions, and this is true to some extent in more widespread subsurface correlation. The alternation of limestone and dolomite has no stratigraphic significance, since one grades laterally into the other in an unpredictable manner.

The insoluble residues of the Ellenburger offer the best qualitative evidence found to date for recognizing subdivisions within the group. The possibility of subdividing the Ellenburger in certain areas of its subsurface extent on the basis of insoluble residues alone has been demonstrated (Cole, 1942; Crowley and Hendricks, 1945). Cloud and Barnes noted characteristics of the chert impurities in the limestones and dolomites on the outcrop peculiar to certain formalions. The characteristics are evident in both the embedded chert and the chert formed at the surface under the processes of erosion. It will be shown that samples taken from surface sections and digested in acid will yield residues that show a qualitative variance from one level of the lillenburger to another. The change in residue quality does not coincide with formational boundaries in every case, but the points of change are sufficiently consistent that the residues offer a clue to formation identification, if not exact definition. The chief assel of the residues is the fact that variations in residue quality can occur with age despite little or no change in major type of sedimentation. The chief weakness of the insoluble residues as an aid to stratigraphic study of the Ellenburger is the fact that residue quality is an expression of facies and can change laterally with change in sedimenlary conditions affecting deposition of insoluble material.

The term "insoluble residue" is here used in the same sense as others have used it (MoQucen, 1931; Ireland, 1936). The samples were treated with dilute hydro. chloric acid or, in some cases, with dilute acetic acid. The residual material is therefore known to be insoluble only in those acids.

One of the objertives of field work on the Ellenturger was to oblain sels of samples from measured sections whose insolubliz residues could be compared with those from subsurface sections. Therefore Cloud and Barnes selected and marked sections that offered the best opportunity for oblaining samples from beds in place. The very carcful and painstaking field work of Cloud, Barnes, and their assistants, principally L. E. Warren and R. L. Heller, has made it possible to collect dependable surface samples for comparison with subsurface samples. It is with great pleasure that this opportunity is used to express appreciation for the excellent manner in which they clarified the field relationshins of the various sections. Grateful acknowled gment is made for their generous coopleration in gathering samples from the field for comparison witl samples from the subsurface.

Other sources of help on the subsurface study of the Ellenburger include various oil companies and geologists operating in north and west Texas. Their generous help 
in making samples and residues available for study made the project possible.

The work of investigation has been carried on under the auspices of the Bureau of Economic Geology of The University of Texas, and the writer wishes to acknowledge the great value of the assistance and encouragement received from the Director of the Bureau.

\section{ACQUISITION AND STUDY OF RESIDUES FROM SURFACE SECTIONS}

The insoluble residue characteristics of each of the Ellenburger formations presented here are revealed in samples from measured seclions in each of the areas mapped in detail by Cloud and Barnes (Pl. I). The samples are from six composite sections, representing the lotal measureable thickness for each of the six areas, and from one incomplete section. The sections are designated as follows:

1. Gorman Falls ...'Tanyard

2. Cherokee Creek

3. Warren Springs-Moore Hollow

4. Barkbone Mountain

5. Johnson City

6. Threadgill Creek

7. Ilano River

Sampling the sections was done in part by Cloud, Barnes, and assistants and in part by the writer, assisted by L. E. Warren. All the sampling was based on rneas. urements by Cloud and Barnes. Preparation of all residues was under the supervision of the writer.

In sampling the Ellenburger, fresh chips were broken from beds at as short vertical intervals as exposures would allow. Chips. from a 5-foot interval were combined to form one sample. Different types of rock occurring in a 5-foot interval were represenled in their proper proporlion so far as sight judgment could allow. Fach sample was crushed in a small jaw crusher and a thorough mixing of fragments from each chip obtained. A uniform portion of each crushed sample, 'averaging about 30 gramis of the material, "was used in making resi. dues. The fines were not screened from the crushed material, but the rock flour resulting from the crushirng was removed by washing and decanting before adding the acid. Solution was carried out in 400-ml. pyrex beakers, using approximately .12 percent hydrochloric acid, or approxi. mately 10 percent acelic acid. After com- plete digestion of the soluble rock the clay-size particles were removed from the residue by washing and decanting. The remaining residue was dried on an electric hot plate and bottled.

This method of collecting and preparing surface samples for study was followed because experience in using residues from the Ellenburger as an aid in stratigraphic study has shown that the mass characteristic of the residues is the most informa. tive, Few, if any, residual materials are individually, diagnostic of a formation. Hence in sampling for residue study, as much as possible of the vertical extent of the 'formation must be included. 'Trench sampling would be ideal but is impractical. Spot sampling at intervals of a few feet will not catch enough of the mass characteristics.

The residues were examined under a binocular microscope, using a magnification of 15.6 diameters for the most part. Light source was a fluorescent lamp with a daylight-type bulb. The data considered were almost entirely qualitative, being quantitative only' to the extent of sight comparison of quantities of malerials.

Residues obtained from the Ellenburger by treating. with hydrochloric acid are made up of four broad types of materialchert, non-clastic quartz, claslics, and accessory constituents. Fach of these types occurs in a variety of forms and combinations, thus producing the qualitative variations that are significant in stratigraphic interpretation. Chert is the most significant material, occurring in a wide variety of textures, structures, and degrees of transparency. The distinction between chert and quartz is somewhat arbitrary, since all types of chert are varieties of the mineral quartz. In describing the residues the lerm quartz is reserved for materia]. with the fracture, luster, and crystal habit of the mineral. By assigning symbols," either colored or drawn, to represent the various materials in residues, the succession found in a section can be presented on a log strip. Correlalion between sections can best be accomplished by matching plotted logs.

Samples from limestone beds in the Ellenburger may be dissolved in acetic acid, in which the dolomite is insoluble. Samples from the limestone portions of several sections, both surface and well sec- 
tions, have been treated with acetic acid for comparison with residues from hydro. chloric acid. Few differences have been discovered between the two types of residues. The acetic acid residues from surface sections have yielded a few conodonts, but they are much too rare to be of use in stratigraphic work. The effervescence from acetic acid is less violent, thus leaving more of the delicate clay and fine clastic aggregates intact. This particular quality of the residues is an aid in distinguishing fine-grained, gray lillenburger limestone from similar Mississippian limestone in the subsurface of north Texas. Soft shale fragments preserved in the acelic acid residues from the Mississippian limestone contain fossil imprints while those from the Fllenhurger limestone do not. Although very closely related to the major sediments as to time of deposition, they may have an entirely independent source. On the other hand, the various types of chert found in the residues represent deposition from solution, just as the carbonates do. Part of the cherts appear to be syngenetic in relation to the enclosing rock, and part have a secondary or epigenetic appearance. The source of the syngenetic cherts may be the same as, or very closely related to, the source of the major sediments. The epigenelic cherts may be the result of al. teration of syngenelically deposited siliceous material, or their silica may have been brought in by circulating ground waters after the deposition of the carbonates and their accompanying syngenetic materials.

Table 2. Genetic classification of residues. ${ }^{1}$

\begin{tabular}{|c|c|c|}
\hline ALLOGENIC & Syngenetic & AUTHIGENIC ${ }^{\prime}$ Epigenetic \\
\hline $\begin{array}{l}\text { Silt } \\
\text { Sand } \\
\text { Shale fragments } \\
\text { Mineral fragments } \\
\text { (e.g., mica) } \\
\text { Siliceous spicules }\end{array}$ & $\begin{array}{l}\text { Chert (segregated) } \\
\text { Shale partings } \\
\text { C.lay masses } \\
\text { Pyrite (crystalline) } \\
\text { Clanconite } \\
\text { Sedimentury feldspar, mica } \\
\text { Fossi] fragments }\end{array}$ & $\begin{array}{l}\text { Chert (interstitial) } \\
\text { Quartz } \\
\text { Siliceous oolite and ooliths } \\
\text { l'yrite (interstitial) } \\
\text { Aubydrite } \\
\text { Replaced fossils }\end{array}$ \\
\hline
\end{tabular}

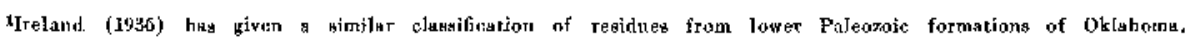

acetic acid residtues do not seem to offer much additional aid in the area and portions of the section where they have been used, the method has not been given an exhaustive Irial. In other areas and portions of the section positive results may be oblained.

\section{EVAI,UATION OF RESIDUES AS AN AID IN ELLENBURGER STRATIGRAPHY}

The insoluble residues obtained from the Ellenburger deposits represent the ac:cessory constituents in the main body of rock. They are the products of minor sources of deposits which were greally overshadowed by the carbonate deposits. The degree of relationship between the sources of these major and minor deposits may vary widely. On the one hand, sand grains and shale fragments in the residues represent . mechanical deposition in the midst of a chiefly precipitated sediment and are syngenetic deposits in relation to the enclosing rock. Although they are lt is conceivable that minor sources of sediments, such as furmished the insoluble malerials, may be modified or completely disrupted by a cbange in conditions too small to be reflected in the major portion of the sediments. For example, the failure of some transporting agent that had been. depositing scattered sand grains in a calcareous deposit would not necessarily affect the deposition of limestone. I ikewise, the modification of chert formation in minor amounts would not necessarily affect the carbonate deposits. However, any change in conditions that modified the type of insoluble accessory materials being deposited would be evident in the insoluble residues. Thus the residues may in some cases afford a more sensitive tool for de-1 tecting changes in conditions than the bulk of the sediments.

Accessory materials undoubtedly exhibit. lateral gradation from one type to another during the same time inlerval, varying with the numerous local conditions influencing 
sedimentation in a basin. Some accessory materials, however, appear to be the result of regional inlluences and carry through minor changes in local conditions. Those changes in residues due to change in local conditions may be used for local correlalion only. A more widespread change due to modification of regional influences may be used for wider correlation. Average temperature and solute content of the water, for examplé, are regional conditions subject to modification that may affect the accessory materials throughoul a sedimentary basin.

In using insoluble residues as an aid in stratigraphic study of the Ellenburger each type of residue material has been carefully evaluated and is relied upon in correlation only within the probable limits of ils dependability. The syngenetic cherls are the most widespread of the insolubles and are the most thoroughly disseminated through the group. This, perhaps, is due to their being rather closely related in method of deposition to the major sediments, which indicates that they are the result of regional influences and not local conditions. By the nature of their occurrence, then, the syngenetic cherts are the most important and diagnostic of the residue materials.

Other significant materials in the residues may be of diagnostic value buit to a lesser degree than the syngenetic cherts. Any of the mechanically deposited materials such as sand grains, shale inclusions, and silty material may occur in zones that can be correlated locally-within the limits of an oil field, for example. Silicified ooliths and oolitic cherts are more likely to be due to specialized local conditions than to widespread influences.

\section{RECOGNI'ION OF THE FI,IENBURGER FROM STUDY OF SAMPLES}

Gross lithology has long been a criterion for recogrizing Ellenburger rocks from samples. Typical Ellenburger limeslones have a high degree of purity, light color, sublithographic texture, and complete absence of any direct evidence of organic origin. Fracture of the limestone is sharp, with a minimum of powdering along the edges of small chips in crushed samples. Typical Fllenburger dolomites have a well developed sucrose texture, are generally light in color, and also exhibit a high degree of purity. These characterislics usu- ally serve to distinguish the group from all rocks found lying immediately above the Ellenburger in the outcrop region. Dolomite in the Edwards formation of the Lower Cretaceous is the only similar rock in the area.

Recognition of the base of the Ellenburger from samples can be quite difficult where similar lithologies are in contact at the systemic boundary. In the eastern and southeastern portion of the outcrop area Ellenburger dolomites rest upon WiJberns dolomites, as illustrated by the Johnson Cily section and the Gorman Falls-Tanyard section (Pl. II). The Wilberns dolomite is usually finer grained than the Ellenburger dolomite. Stratigraphic recognition is aided by a study of insoluble residues. Lowermost Ellenburger dolomites are character. istically lower in residue content, with the residues being marked by the presence of granulated chert and waxy shale flakes. Wilberns dolomites usually furnish more residue, with granular chert predominating and drusy quartz common.

In the western part of the outcrop area silty, somewhat impure Fillenburger limestones containing some glauconite rest on sirnilar limestones in the Wilberns formation, as shown by the Llano River section (Pl. II). Here the texture of the limestones and the glauconite content lurnish clues to stratigraphic identification. The Wilberns limestones are typically granular, in contrast to the extremely fine to sublithographic texture of the Ellenburger limestones, and contain a greater abundance of glauconile. Comparative abundance of glauconite is most easily ohserved in the residues from the limestones.

Residues alone are not a dependable source of evidence for identifying the Wilberns-Ellenburger contact throughout the outcrop area. Ellenburger-type residues, dominated by cherts, and Wilberns-type residues, high in silty, argillaccous material, can be recognized in samples from those formations throughout the outcrop area. But in the eastern sections Ellenburger-type residues exlend down into the Wilberns dolomites, and in the western sections Wilberns-type residues extend up into the Ellenburger. In the eastern sections the boundary can be determined fairly closely from the residues because of a change in the nature of the chert, as noted above. In the western sections, how- 
ever, no widely dependable diagnostic change occurs in the silty, argillaceous residues present both above and below the boundary. Increase in the amount of glauconite is an indication of Wilberns age. This, together with the granular texture of the limestones, seems to be the best criterion for distinguishing Ellenburger from Wilberns in samples from the western portion of the outcrop area.

The transgression of silly, argillaceous residue material across time lines as established by fossil evidence is shown on Plate II. The insoluble material is lypical of Wilberns limestones but does occur in Wilberns dolomites; for example, in the War. ren Springs-Moore Hollow section the material is present in the lower portion of the Pedernales dolomite member. Farther west, in the 'Threadgill Crcek section, the lower half of the Threadgill member of the Tanyard formation yields silty, argillaceous residues. Still farther west, in the Llano River section, the material occurs throughout the Threadgill. The upper limit of the occurrence of silty, argillaceous residues in the Cambrian-Ordovician sections is presented as a transgressing but recognizable boundary on the correlation chart of Plate II.

\section{RECOCNITION OF FORMATIONS IN ELLENBURGER GROUP}

Recognition of the formations in the Ellenburger group from a sludy of systematically sampled sections must be based on rock characteristics alone since no microfaunal evidence is present. The rock characteristics considered in the Fllenburger samples consisted of the lithology and texlure of the original rock and the various types of materials present in insoluble residues from the samples. Standard lithologic logs were prepared of all composite sections that were measured and sampled. In addilion, highly detailed logs of the residues from each section were madc. Comparison of the lithologic and residue Iogs from all the surface sections demonstrated that recognition of the Ellenburger formalions from sample logs is possible to a fair degree of accuracy.

The standard lithologic logs showing texture of the dolomites can serve only as general guides when used alone. The best evidence for recognition of formations is found in the combinations of residue asso- ciations shown on the residue logs. The lithologic logs can be an aid in deciding exact points when used with the residue logs, for it often seems logical to place a formation top where a change in lithology or texture occurs.

Careful study of the highly detailed residue logs showed that the residue malerials most pertinent to the recognition of the formations can be classified as follows:

\section{Non-granular chert Granulated chert \\ Non-clastio: quartz Sand

Consequently a set of black and white and color symbols was devised for showing on logs the occurrence of these materials in the surface sections.

Non-granular chert is that in which no grain could be distinguished under low magnification. Chalky, earthy textured cherts, porcelaneous cherts, and inlermediate types bordering on granular were usually logged as non-granular. Those logged as granular showed a definite grain on the broken surfaces. The granulated chert occurs in very rough irregular fragments that have the appearance of being aggregates of irregular chert grains.

The non-clastic quartz includes fragments of the mineral quartz that are dolomoldic, drusy, or show other evidence of having been deposiled in place in the rock.

The sand grains are rounded to subrounded, usually frosted, quartz fragments. The silt is made up of sill-size siliceous grains which appear to be clastic in origin. Some of the material, however, may be the resull of precipitation and growth of small grains in place. The silt occurs bolh frec and embedded in argillaceous material.

The argillaceous material includes flakes of shale, clay-like masses, and spongy, porous masses not properly described as either itay or shale.

For detailed discussion of residue material. see page 18.

\section{TaNyard Formation}

The outstanding sample characteristic of the Tanyard formation in the standard section area of Tanyard and Gorman Falls (Pl. II) is the predominance of granular 
chert in the residues of all but the uppermost beds of the formation (sample descriptions, p. 36). Non-granular chert ranging from smooth, conchoidal to chalky in ap. pearance may be present but not as abundantly or persistently as granular chert. The granular chert from the dolomitic facies of the Tanyard is characteristically dolomoldic. Drusy quartz is fairly common in the formation. The chert and quartz of the formation are largely interstitial in occurrence below the weathered surface, although large masses of chert form at the surface as a result of concentration under weathering processes. Thus, crushed samples of Tanyard rocks do not commonly show free fragments of chert, even though the percentage of insoluble residue may be high, Oolitic chert, both granular and non-granular, appcars sporadically in the Tanyard section.

In the eastern seclions the Threadgill member of the Tanyard formation can be distinguished on the logs from the Staendebach. The Threadgill mernber contains the special type of granular chert best described as granulated chert. The chert appears as very rough, highly granulated fragments, added to the other chert materials common to the Tanyard. In some samples the granulated chert becomes the most abundant material. Green and red waxy shale flakes also appear more consistently in Threadgill residues than in Staendebach residues. Threadgil] samples average a noticeably smaller percentage of residue material than either Staendebach or Wilberns dolomite samples.

A marked change occurs in the nature of the residues from Tanyard samples in moving westward across the outcrop area. The residue log of the Threadgill Creek section, Gillespie County (PI. II), shows normal Tanyard-type residues from the upper half of the member, but the lower half has the argillaceous, silty residue material similar to residues from the under. lying Wilberns. In the Llano River section, localed still farther west in Mason County, the silty, argillaceous residues have replaced cherty residues through all of the Threadgill and have transoressed slightly into the base of the Staendebach. Mosl of the Staendebach section has normal Tanyard residues, with one notable feature: the granulated chert typical of Threadgill in the eastern sections is present in the Staendebach in the Llano River section. Thus, the upper Tanyard can be recognized from residue samples in the western outcrops, but the lower portion is better distinguished by the subgranular texture of the limestones, as noted previously.

The uppermost beds of the lanyard, averaging about 100 feet in the outcrop sections, do not furnish residues that are typical of the remainder of the formation. The cherts in the upper beds are largely non-granular and are similar in nalure to those from the overlying Corman forma. tion. The chief distinction between the residues of the upper beds and those from the Gorman is the absence of sand in the Tanyard residues. This criterion appears dependable throughout the outcrop area.

It will be noted on the lithologic logs (Pl. II) that the texture of the Tanyard dolomites ranges from coarse to fine, with coarse and medium predominating. The coarsest dolomiles are found in the dolomitic facies of the Threadgill member, with the Staendebach dolomite grain averaging somewhat smaller. The Tanyard limestones all have a very smooth fracture and are subgranular. In the eastern sections the limeslones are pure and very light in color. In the western sections the lower limestones become grayish and furnish silty, argillaceous residues.

\section{Gorman Formatron}

Residue logs of the Gorman formation outcrop sections (Pl. II) show the chief constituents to be nor-granular chert and sand. (Sample descriptions of type section, p. 26.) Subordinate materials are granular chert, quartz, shale, and other argillaceous material. The non-granulur chert consisls largely of smooth opaque and smooth translucent varieties but includes some chalky and subporcelaneous. The chert for the most part is not interstitial, and free fragments are found in the crushed samples of the rock. The chert occurs in thin seams, beds, and irregular nodules in the limestones and dolomites and because. of its manner of occurrence is not typically dolomoldic. Zones of oolitic chert are present. Near the middle of the formation some of the cherl usually contains embed. ded sand grains. The sand in the Gorman 
residues is composed of pure, frosted quartz grains, and the larger grains are rounded. The sand occurs both as scattered, individual grains and as sandy zones in the formations. Grain sizes in the sandy zones show poor sorting, ranging from fine to medium coarse.

The dolomites of the Gorman are persistently finer in texlure than the ']anyard dolomites in the eastern Ellenburger sections. Grain sizes are fine to very fine. However, in the Llano River section the lower dolomites of the Gorman are coarse in texture.

The occurrence of sand together with the grain size of the dolomite in the eastern area furnish the criteria for determining both the base and the top of the Gorman from samples. The overlying Honeycut contains very little sand except in the lower 50 feet of beds.

\section{Honeycut Formation}

Residues from the Honeycut formation are composed largely of non-granular chert, simitar to that in the Gorman. (Sample descriptions from Gorman. Falls-Tanyard section, p. 23.) In general, there is a slightly smaller percentage of insoluble material in the Honeycut than in the Gorman. Scarcity of sand in the Honeycut residues, however, is the most noticeable difference in surface sample residues from the two formations. Thus, recognilion of the IIoneycut from residues must be based largely on the predominance of non-gramular cherl, with the absence of the sand that characterizes the Gorman. Dolomites of the Honeycut art similar to those of the Gorman but show a tendency to be finer textured. Most of the microgranular dolomite of the Ellenburger group is found in the Honeycut samples.

POINTS OF CORREIATION ON THE ELEEN. BURCER SURFACE SECTION SAMPLE LOGS

The type section for the Fillenburger group, as designated by Cloud and Barnes (1948), is the composite seclion made up of their Gorman Falls, Spicewood Creek, and Tanyard sections. They designated the composite section made ur of their Warren Springs and Moore Hollow sections as a standard section for the Ellenturger. The logs of the two composite sections therefore are type logs to which other logs should be referred. Several correlative points are evident on the two logs that can be recog. nized on the logs of the other surface sections.

The most marked and persistent feature of the logs is the change on the residue logs from non-granular cherts above to granular cherts kelow at a level near the top of the Tanyard formation. 'The level marked by the change serves as a dependable correlative horizon for relating the sections on the basis of sample evidence. When the logs are leveled on that horizon, the tops of the Tanyard as determined by field and lossil evidence are not far from alignment. Thus it is felt that any section of the Ellenburger including this portion of the section can be closely correlated with the type Ellenburger section.

The presence of sand in the Gorman and in the base of the Honeycut and the absence of sand in the Tanyard are other characteristics appearing on all residue logs of those formations. Hence, the lowest occurrence of sand makes a fairly good correlative poinl, marking approximately the base of the Gorman.

A granulated chert zone is present in the Tanyard on all residue logs showing the complete formation. 'The granulated chert appears in the Threadgill member in the eastern sections and in the lower part of the Staendebach in the westernmost section.

The gramilated chert zone is a good correlative marker in the facies of the Ellenburger represented by the castern sections but indicates somewhat younger beds with changing facies westward.

A sandy cherl zone is lypically present near the middle of the Gorman formation. The chert is usually free of sand even though sand is abundant in the residue. But in this particlar zone many of the sand grains are embedded in the chert.

The horizons present on the residue logs listed above furrish the means for correlating the logs of the sections and are a valuable aid in recognizing formations from sample information. No distinclive fcature of the gross lithology occurring persistently at a given level is evident from the sample study.

PROBLEMS IN RECOCNIZING ELLENBUR. GER FORMATIONS IN THE SL\}BSURFACE

The subdivision of the kllonburger into formations resls primarily on faunal evi- 
dence. But in choosing formation bound. aries Cloud and Barnes used the best physical breaks available in the rather homogeneous group of beds. Thus the formations are essentially time-rock units with fairly mappable boundaries marked by changes in such physical characters as grain size of the dolomile, occurrence of sand, and nature of contained chert. When physical evidence fails, fossils can be sought to help establish formation boundaries in surface mapping. Each lormation carries a definite age meaning.

Recognition of formalions from subsur. face samples must be based on physical evidence alone. The point of grealest concern is whether or not the physical evidence available continues to have the same age significance that it has at the surface. Evidence from the surface section sample logs supporls the idea that some of the physical evidence usable in correlating the sections does have age significance. The most dependable horizon recognizable in the samples is the level marked by the change from non-granular to granular chert in the residues. This change occurs consistenlly near the top of the Tanyard formation, regardless of the localion of the section. Other marked zones; such as the granulated chert zone of the Thread. gill member and the sandy chert zone of the Gorman formation, appear to have consistenl age significance over a large area in the eastern portion of the outcrop area. In a westerly direction the granulated chert zone to some exlent appears to migrate up the sechion across time lines. It is in the eastern portion of the outcrop area that the typo and standard sections are located. Therefore, the suc. cession as developed in the eastern sections may be thoughi of as representing typical Ellenburger facies. Sample log evidence indicates that where typical Ellenburger facies is developed the physical evidence has age significance, and the time-rock unit type of formation can be recognized on the basis of that evidence.

\section{CORRELATION OF ELLENBURGER SUB- SURHACE SECTIONS}

\section{Central Texas to North Texas}

Hundreds of wells have penetrated a portion of the Fllenburger section in the subsurface of north-central and north Texas.
A few wells have drilled through the group, and many have drilled several hundred feet. Enough sections are available for general' corrclation of the Ellenburger beds of the area with the formations defined at the surface.

Plate III presents the plotted logs and stratigraphic correlation charl for a series of sections on a lraverse from the southern side of the Llano uplift norlhward to northerm Archer County. All formations described at the surface can be recognized along the traverse at lcast as far north as Erath and Somervell counties. In northern Archer County the Tanyard-Gorman boundary can be determined, but available criteria fail to distingussh the Gorman-Honeycut boundary or to establish clearly the base of the Tanyard. hicsidues from the enlire upper Ellenburger section become notably arenaceous in extreme north Texas. It is felt that the subsurface Ellenturger sections in this area can best he correlated with surface sections exprosed in the Wichita Mountains of Oklahoma.

Plate IV presents the sections and their correlations on a traverse from Fisher County eastward to Somervell Counly.

The well seclions of north Texas have been correlated with the surface sections very largely on the basis of evidence on the residue logs. The best control point for correlaling the sections is again the conlact of the granular and non-granular chert zones, as was true with the surface sections a]one. This characteristic change in chert type has been observed in all the wells invesligated in north Texas that contain. that particular porlion of the section. Because of ils persistent appearance near the same stratigraphic level throughout the outcrop area, the level is considered a fairly dependable time marker. For this reason the top of the Tanyard has been placed at the top of the granular chert zone in the subsurface section's. This probably results in a slight error in correlating with the surface sections, but it does offer a consistent correlation of the top of the formation from well to well.

The criteria for recognizing the base of the Tanyard change wilh geographic location. The problem seems identical with that encounlered at the surface. The most easterly wells that pass through the Ellen. burger encounter a dolomite section below 
beds bearing fypical Tanyard residues (Seaboard Nò. 1 Dawson in Hamilton County, Pl. IIS, and MeCarthy No. l Hedrick in Erath County, Pl. IV). Residues from this lower dolonite section are similar in nature and abundance to those from the Pedernales dolomite member of the Wilberns formation. They are therefore considered Cambrian in age. The lower portion of the Tanyard in the easterly sections contains residues typical of the Threadgill member; that is, a proportionalely small amount of residue containing waxy shale flakes and some granulated chert. Sections penetrated so far indicate that the Threadgill and Staendebach members of the Tanyard are recognizable in an area extending from western Easl land County to eastern Erath County in width (Pl. IV) and reach. ing northward at least through the latitude of the north edge of Erath County. The top of the Cambrian in the eastern sections in this area is placed at the point of sudden increase in amount of residue, which contains an abundance of granular, drusy, dolomoldic chert and drusy quartz.

In moving west across the above described area the Upper Cambrian residues change from predominantly chert to silty, argillaceous material. On the basis of evidence seen in the surface sections it is assumed that the change to silty argillaceous residues cortinuies upward into the Tanyard formation in a westerly direction. In eastern Taylor Gounty (Pl. IV) the lowermost Tanyard beds apparently contain such residues. Therelore, from about the longilude of eastern Taylor County westward the Tanyard-Cambrian boundary is best determined on the granularity of the limestone, if present, and abundance of glauconite in the Cambrian, as is the case in the western portion of the outcrop area.

Determination of the Gorman-Honcycnt boundary can be made with less assurance than the other stratigraphic boundaries in 1.he section. The sandy characler of the Gorman residues is a general guide throughout inost of the norlh Texás arca. Accordingly the lop of the Gorman is placed at the tóp of the persistently sandy residiuc: section found in wells in the area extending from the outcrop of the Ellenburger northward to approximately the Archer-Young County line. From aboul. this' latitude northward the entire upper
Ellenburger section furnishes sandy residues, and the Gorman and Honeycul have not been distinguished from each other in sections in Archer and Wichila counties.

It is the opinion of the writer that complete Ellenburger sections in the ArcherWichila County latitude include beds that are younger than Ellenburger at the outcrop. A careful comparison should be made of sample criteria from the subsurface sections with sample criteria from surface scclions in the Wichita and Arbuckle Mountains of Oklahoma. Such a comparison may reveal evidence for correlating the extreme north Texas Ellenburger with formations of the Arbuckle group. Should this be so, the youngest Ellenburger beds of norlh Texas may correlate with the upper Kindblade or lower West Spring Creek formation of Oklahoma. Cloud and Barnes (1948, p. 65) considered the West Spring Creek and approximately the upper third of the Kindblade to be younger than Honeycut at the outcrop.

Plate IV presents the thinning of the Ellenburger group westward by erosional loss at the top and probably depositional thinning of the Tanyard at the base. In Taylor Counly the Honeycut is missing, 185 feet of Gorman remains, and the Tanyard is 370 feet thick. In Fisher County all the Foneycut and Gorman section is missing, and only 300 feet of Tanyard is present to represent the group.

Prolific oil production from the Ellenburger has been found in only one field to date in north Texas. The K. M. A.-Ellenburger field of Wichita and Areher counties is producing in part from the top of the Tanyard and in part from the base of the Gorman formation (Shell No, 18F Preslon, Pl. IIJ). Crowley (1946) ${ }^{2}$ has shown that there is a remarkabje difference in the initial polential production from the two formations. The wells completed in the Tanyard in general have inilial polenlials grealer than 1,000 barrels of oil per day. The wells completed in the Corman in general have potontials less than 500 barrels per day.

\section{Central Texas to West Texas}

Wells drilled in an area extending westward from the southernmost edge of the

\footnotetext{
${ }^{2}$ Contact of Crowley's Units $B$ and $C$ is the Gorman. Turyard conturt of this paper.
} 
Ellenburger outcrop area encounter a uniform section of Ellenburger beds. Plate V presents the logs and a correlation charl for a traverse extending from Blanco County westward to Crane County. The sections have been correlated almost entirely on the basis of the residue logs. Residues are sufficiently similar to those of the outcrop) samples to permit a reasonabje corrclation.

The Tanyard formation is recognized by the granularity of its chert residues. Most of the Tanyard sections contain a granu. lated chert zone, similar to the Tanyard of the Llano River section in Mason County (Pl. II). The major change in residue characteristics is the presence of sand in the west Texas sections. The Tanyard is underlain in some sections by a highly glauconilic limestone which is tentatively correlated with the Wilberns formation of central Texas. This correlation admittedly is debatable, it being possible to argue that the glaucontic limestone facies of the Wilberns has simply migrated up the section into beds of Ordovician age. The Tanyard of west Texas is less than half as thick as that at the outcrop. Most Ellenburger sections in west Texas have about 300 feet of Tanyard. Lithologically the Tanyard of west Texas is a medium to coarse dolomite. Good porosity is evident in some portion of most sections.

The Gorman-Tanyard boundary is placed at the top of the section dominated by granular chert as in north Texas. The Gorman residues of west Texas contain a slightly larger percent of granular chert than do those of central Texas, but non. granular chert is a persistent and usually dominant constituent of the Corman residues. Also the granular chert in the Corman is extremely fine to subgranular. Sand is commonly present, usually as free grains. But a non-granular, sandy chert zone in the upper part of the formation is characterislic. The upper boundary of the Gorman is not a well-defined horizon but must be determined by correlating horizons above and below the boundary, as noted below.

The upper part of the Gorman is composed of very fine dolomite, showing little evidence of porosity. The lower portion of the formation is made up largely of medium to coarse dolomile. These lower beds exhibit sporadic zones of porosity.
All the Ellenburger above the Gorman in west 'Texas is here placed in the Honeycut formation. Correlation of the residue logs and thicknesses of sections indicate that only a minor portion of the Ellenburger of west Texas is younger than the youngest Honeycut exposed at the outcrop (PI. V). There is no marked physical evidence for defining a formation younger than Honeycut. Therefore, it is considered logical to place the youngest Ellenburger beds in the subsurface of west Texas in the Honeycut, even though some of those beds may be younger than any Honeyeut al its type locality.

The residues of the Honeycut are largely non-granular chert, with some sand and granular chert. Both sand and granular chert occur in slightly smaller percentages than in the Gorman. One gramulated chert zone occurs rather persistently in the lower part of the formation. This granulated zone and the sandy chert zone in the upper part of the Gorman serve as correlative aids in determining the Gorman-Honeycut boundary. The boundary is placed between the above described zones at a point on the residue logs where there is a slight increase in residue percentage, with an increase in the percentage of granular chert in the residue. This point is usually about midway between the granulated chert zone of the Honeycut and the sandy chert zone of the Gorman.

The Honeycut in most localities contains a sublithographic, white limestone member in its upper part, with the remainder of the formation being composed of very fine to extremely fine dolomite. Any porosity present is correspondingly fine. The formation is rendered more porous and permeable by fracturing in areas of sharp structural disturbance.

The series of sections and logs presented on Plate $\mathrm{V}$ are designed to establish a reference cross section to which other sec. tions in west Texas can be referred. The traverse of the sections follows the trend of what may be termed the "normal" facies of the Ellenburger. That is, all the formations are present and contain lithol. ogy and residues similar to the type and standard sections of the Ellenburger. Farther westward this facies must grade into the impure dolomitic rocks making up the El Paso formation exposed on 
Beach Mountain in the Van Horn region. Southward the Ellenburger of west Texas must eventually grade largely into the impure limestone facies represented by the Marathon formalion exposed in the Marathon uplift. But until the Ellenburger loses its identifying characteristics in ad. jacent facies it should be possible to recognize its formations by comparison. of insoluble residue logs.

Excellent oil production has been obtained from all portions of the Ellenburger seclion in west Texas. Both fracture and interstitial porosity occur, depending on the geological history of the structure. The sections on Plate $\mathrm{V}$ include the Humble No. 4.C Fee, a well in the Todd field of Crockett County where Ellenburger production is from the Honeycut formation.

\section{SYSTEMATIC DISCUSSION OF RESIDUES ${ }^{3}$}

\section{CherT}

The term "chert" is applied to the cryp" tocrystalline varieties of quartz found in the residues, regardless of color. The chert is composed mainly of microscopic fibers of chalcedony or particles of quarlz, or a mixture of both. The quality of the chert that has proven to be diagnostic in studying the Ellenburgor is texlure. Three main textural groups found in the Ellenburger residues have been designated as smoot $h$, granular, and chalky. The majority of the cherl encountered, can be readily placed in one of the major groups, with a small minority showing intermediate nondeterminate characteristics. Each of the textural groups shows variations in appearance, making it possiblo to subdivide each group into recognizable types.

The chert described as smooth textured has a conchoidal to flat lracture surfaco devoid of roughness. It has no distinctive structure, crystallinily, or granularity. Some of it is botryoidal in form. The types recognized are ordinary, chalcedonic, and porcelaneous. The ordinary smooth chert typically has a flat fracture, may be any color but is usually while or gray, is mostly opaque but some variations show

\footnotetext{
IIn Fune 1946 a group of geolorists Iatuilitus with re.tidue work met in conference in MidIand, Texas, and worked tout a fystomatic classitivation baserl on appearance and agreed an descriptivi: terms for muteriuls found in residlues. Al] diacriptiona of the appearance of Ellusburget reaiduen follow the rutline published an a result of the cudfreronec,
Sce Ireland and othorg (1947).
}

slight translucency. It occasionally presents a mottled or flocculated appearance. It is generally homogeneous but may have slight evidence of granularity or crystallinity. The chalcedonic smooth chert is transparent to translucent and is described as smoky, milky, waxy, or greasy in appearance. Variations are tinted with various colors, but the most common is light blue-gray. It can also be fincly mottled or have flocculated inclusions. The fracturo is more usually conchoidal than flat. The porcelaneous type of smooth chert has a very smooth fracture surface, is opaque to subtranslucent, and is typically chinawhite, resembling china-ware or glazed porcelain. It grades juto an extremely fine granular chert resembling unglazed porcelain.

The granular chert found in the Ellenburger 'residues is composed of distinguishable grains, granules, or druses. It has an uneven, or rough, fracture surface and a dull to slightly glimmering luster. Fragments of the chert range from hard to soft. Two types recognized are designated as compact and granulated. The compact type is mostly homogenous, has relatively uniform-sized grains, and some of it appears saccharoidal. The grain size varies from an extremely fine type that is gra. dational from the smooth porcelaneous up to a size that is easily distinguishable under 10-power magnification. The grains rarely reach $0.5 \mathrm{~mm}$ in size. The granulated type of granular chert is composed of tiny grains or granules of chert tightly to loosely held together in small, irregular masses or fragments. The individual grains making up the small masses may appear saccharoidal, grade from angular to drusy, and range from extremely fine up to grains $0.5 \mathrm{~mm}$ in sizc. This type of chert seems always to be well disseminated through the enclosing carbonale rock and is found more commonly in dolomite than in limestone.

The chalky chert in the Ellenburger residues is so called because of its textural rescmblance to chalk. Much of it bears a strong resemblance to tripolite and may be tripolitic in origin in that it may represent an aggregation of siliceous particles, the particles being possibly colloidal in size. Some of the chers may be an alteration product formed by the leaching of other 
kinds of chert, notably the smooth vari-. eties. Fragments have an uneven or rough fracture and usually a dull or earthy ap. pearance. Somo varielies are extremely fine porous.

All the Ellenburger cherts exhibit a variety of structures. The most common structural features are described as porous, dolomoldic, oolitic, pseudo-oolitic, oomoldic, lacy, drusy, banded, and dolomorphic. In addition, the chert may be sandy, silty, spicular, quartzose, and very rarely fossilferous.

Dolomoldic chert contains dolomolds, a dolomold being a rhombic opening left in an insoluble residue by the solution of an embedded dolomite crystal (Ireland and others, 1947). The occurrence of the dolomolds may vary from widely scattered individual openings to very closely spaced, interconnecting openings. The Iatter occurrence results in a skeleton-like structure and is described as siliceous skeletal dolomolds. The skeletal dolomolds are interstitial chert filling what otherwise would be pore space belween the dolomite crystals.

Oolitic chert contains ooliths (DeFord and Waldschmidt, 1946). Ooliths as applied to insoluble residues of the Ellenburger are spheroidal bodies with a nucleus or contral mass enclosed by one or more surrounding layers of the same or different material. The ooliths are typically siliceous but are very rarely composed of clay, pyrite, or limonite. The ooliths in some cases are of different color and texture than the surrounding matrix. The occurrence varies from widely scattered to very closely spaced, the latier occurrence forming essentially a siliceous oolite. The ooliths also occur frec or in loosely held aggregates. The ooliths grade from very small to large but generally average about $1 \mathrm{~mm}$ in size. Internally the ooliths have either a distinct or indistinct nucleus surrounded by concentric, radiate, or massive material. Externally the ooliths are smooth or covered with very fine druse.

Pseudo-oolitie chert contains rounded, pellet-like bodies with no peripheral layer, some of which do not exhibit sharp distinction belween pellet and matrix. Origin of this particular structure is obscure and possibly varied. The pellets possibly are ooliths with the outside layer absorbed in the process of replacement, or they may result from replacement of pellet limestone. A similar structure has been de. scribed as pseudospicular because of its resemblance to the pattern formed by the spicular meshwork of certain lithistid sponges (Cloud, Barnes, and Bridge, 1945, p. 136).

Both oolitic and pseudo-oolitic chert may be largely the result of replacement. The replacement possibly involved the spherical bodies only, or it could have affected both bodies and matrix.

Oomoldic chert contains spherical cavities formerly occupied by ooliths, each oponing being an oomold. The size of the oomolds ranges from microscopic to easily megascopic, and the average is approximately $1 \mathrm{~mm}$ in diameter. Their occurrence varies from widely scatlered to very abundant. If the oomolds are so abundant that the constituent chert makes up 25 per. cent or less of the mass, the chert is described as skeletal oomoldic.

Lacy structured chert is a highly porous chert with irregular openings, the constiluent chert comprising 25 percent or less of the mass. This chert is largely in. terstitial material, filling irregular spaces in the carbonate rock that would otherwise be porous. Rarely, the lacy chert appears. to be organic in origin, possibly associated with some form of plant life. In the latter case the chert is not interstitial in character but simply embedded.

Drusy chert is in part, at least, encrusted with subhedral quartz crystals. Size of the crystals ranges from microscopic to megascopic. The granular cherts are much more commonly drusy than the smooth or chalky cherts.

Banded chert is made up of layers with either textural or color variations. The layers aro microscopis or megascopic. They are flat, as in banded vein filling, or curved, suggesting concretionary structure.

Dolomorphic chert is formed from previously dolomitic or dolomoldic chert whose dolomite rhombs have been replaced or their molds refilled with another mineral. "Dolomorphic" is synonymous with "dolocastic" as used by Cloud, Barnes, and Bridge (1945) but is preferable in order to avoid confusion with "dolocastic" as used by other writers (McQucen, 1931). 
To be present in insoluble residues, dolomorphic chert must have the dolomite rhombs replaced or their molds filled with an insoluble mineral. It is rare in Ellenburger residucs.

Spicular chert contains siliceous or silicified spicules, chiefly sponge spicules. Generally the spicules occur as individual needle-like bodies embedded in the chert, but in some samples the meshwork formed by a mass of the spicules is preserved. Occurrence of the spicular chert is indicalive but not absolutely diagnostic of certain levels of the Ellenburger.

Quartzose chert contains inclusions and veins of crystalline quartz, ranging from microscopic to megascopic.

\section{Quartz}

Quartz in the Ellenburger insolubles means the nondetrital occurrence of the crystalline, colorless, clear to cloudy min. eral. It occurs in euhedral, subhedral, and anhedral forms. The euhedral quartz occurs as doubly terminated crystals embedded in the carbonate rock and as free crystals in the residues. The crystals vary from microscopic to megascopic in size and from fine, needle-like to short and stubby in shape. The subhedral quart; occurs chiefly as drusy encrustations on rock surfaces. When the encrustations have been removed from carbonate rocks by solution they occur in the residue as free or clustered, partially developed crystals. The anhedral quartz shows no outward crystal development. It exhibits textures ranging from smooth, glassy to granular and granulated.

\section{Cinstics}

The constituents of clastic origin found in the Ellenburger residues are the argillaceous materials - clay and shale; silty material; and sandy material. These constituents occur generally disseminated through the carbonate rock but may occur as small, discontinuous seams or partings. All the material included in this calcgory is considered to be detrital in origin. This distinction becomes difficult, and many times a matter of individual judgment when dealing with finely divided, probably precipitated silica and fine silt.
A large portion of the argillaceous ma terial in killenburger residues is clay-like in appearance and is here referred to as clay. It occurs interstitially in limestone and dolomite, in two principal forms. One form is best described by the term spongy and occurs in porous, earthy, fragile masses. The other form is flaky, the flakes being usually very crinkled and irregular in shape. 'The clay exhibits many of the structural forms found in chert including dolomoldic, skcletal dolomoldic, lacy, oolitic, or oomoldic forms. It also contains silt or sand grains in some occurrences. The color generally is dull gray to white, but shades of purple, red, and green occur. The flaky form is much more abundant in limestone than in dolomite.

The shake in Ellenburger insolubles occurs as thin partings and interstitial fillings in the limestone and dolomite. In texture it grades from waxy to granular and is hard to soft in character. The majority of the shale is some shade of gray, but green is common, with maroon, brown, and purple being more rare. Laminated, porous, dolomoldic, oolilic, and oomoldic forms occur. Impurities make thè shale silty, sandy, micaceous, pyritic, or glauconitic.

Silty material in the residues is characterized by detrital quarlz grains of silt size, that is, larger than clay particles, and with a maximum of approximately 1./16 $\mathrm{mm}$. The sill occurs in the residue as loose grains or as poorly to well consolidated aggregates. The aggregates are usually held together by an argillaceous matrix. In some occurrences the silty material is sandy, glauconitic, pyritic, or micaceous. In addition the well-consolidated aggregates exhibit porous, dolomoldic, oolitic, or oomoldic structure.

The sandy portion of the clastic material in the residues occurs largely as loose grains in the residues but also is present in poorly to well-consolidated aggregates. The aggregates are in a shale, chert, or quartz matrix. 'The grains are, with rare exception, composed of clear quartz. They range in size from just above silt size to. more than $2 \mathrm{~mm}$. The most common form is subrounded to rounded with a frosted surface. A minor portion of the sand found in the Ellenburger is angular. Still fewer of the grains exhibit secondary 
growth. The sand occurs in laterally discontinuous zones in the carbonate rocks. The amount of sand in the zones varies from widcly scattered grains to very abundant. But rarely does the sand become abundant enough to form sandstone. Some zones are gradalional al the top and bottom, while others show an abrupt disappearance of sand from the section at either the top or bottom of a zone.

\section{Accessory Mateilials}

Accessory materials are those that occur sporadically, or more or less continuously in small amourts, in the Ellenburger residues. These materials are bolh mineral and organic in nature. Brief inention of each follows.

Pyrile is the commonest accessory. It occurs as interstitial filling and as individual crystals. The crystals range from microscopic to megascopic in size. The pyrite is often associaled with waxy shale partings in the rock, occurring as minute crystals embedded in the shale. Some of the mineral called pyrito may actually be marcasite, as distinction between the minerals in small oceurrences is difficult.

Mica, commonly muscovite, more rarely biotite, occurs as very small, thin flakes. The flakes occur either free or embedded in the shale or any of the aggregates found in the residues.

Feldspar appears rarely in the residues as minule, light-colored crystals, probably sedimentary in origin. Feldspar also occurs as detrital grains at certain places in the Ellenburger.

Limonite is more common in residues from surface samples than from well samples. Commonly it appears to be replacements of pyrite.

Anhydrite appcars erralically in subsurface sections of the Ellenburger, usually in a clear, crystalline form. The common occurrence of anhydrite in drill. ing muds makes it difficult to determine small arnounts in place in well samples.

Glauconile occurs in the residues usually as small grains, either free or embedded in shale or silty aggregates. It occurs also as interstitial filling and is dolomoldic when thus occurring in dolomite. Glauconite is more common in the lower portion of the Ellenburger than elsewhere.
Millerite, in typical needle-like crystal clusters, occurs very rarely.

Fossil frayments are too rare and nondiagnostic to offer faunal cvidence with correlative significance. The commonest fragments are sponge spicules, either froe or embedded in chort. Both simple, needlelike forms and six-pointed, hexactinellid types are found. Rarely small gastropods and fragments of brachiopods in siliceous replacements are found. As noted above, a few conodonts have been oblained from acetic acid residues of limestone samples.

Beekite is a form of chalcedonic chert associaled with fossil replacment. The cherl forms a series of rough, buttonshaped bodies rrade up of roughly concentric rings of chert, partly or wholly covering the fossil surface. The malerial is Irequently observed on the outcrop, and fragments of the beekite bodies appear sporadically in the residues.

Other insoluble minerals and materials than those mentioned above undoubtedly oecur in trace amounts in the Ellenburger residues. An exhaustive study and identification of all the more rare constituents of the residues has not bcen attempted by the writer. Coldich and Parmelce (1947) have published detailed analyses of samples from portions of Ellenburger surface sections.

\section{REFERENCES CTTED}

Brainfro, A. E., Batowin, II. L., Jr., and Kexte, I. A. (1933) P're-Pennsylvanian stratisraphy of Front Bange in Calorado: Bu\}l. Amer. Assoc. Petr. Geol., vol. 17, pp. 375-396.

Clotid, P. E., Jr., and Barnes, V. E. (1948) The Ellenhurger sroup of central Texas: Univ. Texas Pub. 4621, Junc 1, 1946, 473 pp.

C, and BrtDGE, Josinh (1945) Stratigraphy of the EIlenburger group in central Texas-a progress report: Univ, Texas l'ub. 4,301, Tan. 1, 1943, pp. 133-161.

Cole, C. T. (1942). Subsurface study of Ellenburger formgtion in west 'lexas: Bull. Amer. Assoc. P'etr. Gcol,, vol, 26, pp. 1398-1409.

Crowu.ey, A. J. (1946) Subdivisions of the Ellen. burger limestone in the southwestern part of the K.M.A. oil field, north-central Texals: Univ. Texas Pub. 4301, Jan. 1, 1943, pp. 191195.

and H.sponicks, Leo (1945) Lower Ortovician and Upper Cambrien subsurface subdivision in north-central. Texas: Bull. Amer. Assoc. Petr. Geol., vol. 29, pp. 413-425.

Dake, C. L., and Bribge, Jostah (1932) Faunal correlation of the Filenhurger limestone of Texas: Bull. Gcol. Soc. Amer., vol. 43, pp. 725.741. 
Decker, C. E. (1939) Two lower Paleozoic groups, Arbuckle and Wichita Mountains, Oklahoma: Bull. Geol. Soc. Amer, vol. 50, pp. 1311-1322.

DeF́ord, R. K, and WatnschmidT, W. A. (1946) Oolite and oolith: Bull. Amer. Assoc. Petr. Gcol., vol. 30, pp. 1587-1588.

Goldich, S. S., and Parmelee, E. B. (1947) Physical and chemical properties of Ellenburger rocks, Llano County, Texas: BıIl. Amer. Assoc. Petr. Gcol., vol. 31, pp. I9822020.

Ireland, H. A. (1936) Use of insoluble residues for correlation in Oklahoma; Bull. Amer. Assot. Petr. Geol., vol. 20, pp. 1086-1121.

- and others. (1947) Terminology for itsoluble residues: Bull, Amer. Assoc. Petr. Geol., vol. 31, pp. 1479-1490.

KuNG, P. B. (1937) Geology of the Marathon region, T'exas: U. S. Geol. Surv. Prof. Paper 187, Aug. 10, 1938, 148 pp.
McQueen, H. S. (2931) Insoluble residues as a raide in stratigraphic studics: Missouri Bur. Geol. and Mines, 56th Bien. Rept., Appendix I.

PAIGE, StDneY (1912) Description of the J Jano and Burnet quadrangles: U. S. Geol. Surv. Geol. Atlas, Llano-Burnet folio (no. 183), I6 pp.

Richanoson, G. B. (1909) Description of the El Paso district: U. S. Geol. Surv. Geol. Atlas, El Paso folio (no. 166), ll pp.

Sellaros, E. H. (1933a) The Paleozoic and prePalcozoic systems in Texas, in The Geology of 'Texas, Vol. I, Stratigraphy: Univ. Texas Bull, 3232, Aug. 22, 1932, pp. 1-238.

(1933b) Thickness map of the Ellen. burger limestone in central Texas: Univ. Texas, Bur. Econ. Geol.

(1938) Map showing distribution. of Lower $\mathrm{O}_{1}$ devician in Texas (advance print): Univ. Texas, Bur. Econ. GeoT.

- and Hendnicks, Leo (1946) Structural 'map of Texas, $3 d$ ed, revised, Univ, Texas, Bur. Econ. Geol. 


\section{SAMPLE DESCRIP'TIONS}

\section{Gorman Falus Section, San Saba and Lampasas Counties, Texas}

Honeycul formation, 0-325 feet-

Dolonite-extremely fine, very light gray.

Resune: Clay-sponge-like, yellow. Silt-fine quartz. Chert-trace smooth, whitc, grading to chalky. Sand-few fine, rounded frosted grains. Sipicule-fine, needle-like. Dolomite-xtremely fine, ash-yray, 50 percent. Limestone-.. smooth ash-gray, 50 percent

Rrsidue: Clay-sponge-like and flaky, white. Silt-quartz, grading up to very fine sand. Sand-sinall amount, grading to silt. Chert-lrace white, smooth, very roughly nodular.

Limestone-smooth, very light gray

Rrsinve: Clay-crinkled llaky, light buf, some white. Chert-trace smooth, light buff. Silt-trace,

Dolomite-extremely fine, ash-gray

Residus: Clay-sponge-like, lacy.

Limestone-smooth, dove-gray, 90 percent. Dolomite-extremely fine, light gray, $10^{\circ}$

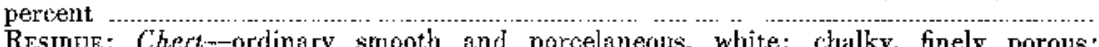
RESIDve: Chert-ordinary smooth and porcelaneous, white; chalky, finely porous ing. Clay sponge-like, white to buff.

Dolmite-extremely fine, light cream-colored, 50 percent. Limestone--smooth, gray, 50 pereent

Resivuv: Clay-sponge-like and flaky, white, some meroon. Chert-small amount bard, chalky. Spicules-fine, needle-like, some with extremely fine cnd filament.

Dolonite-extremely fine, light cream and ash-gray

Resimue: Clay- sponge-like, grayish, lacy. Chert-small amount chalcedonic, concretionary. Qutartz-trace anhedral, rough fragment. Silt-small amount, very fine. Spicules-lew fine, needle-like.

Dolomitc-extremely fine, light gray. Limestone-some smooth, gray. Chert-some

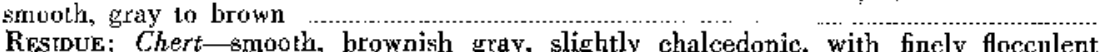
Restoue: Chert-smooth, brownish gray, slightly chalcedonic, with fincly flocculent spongo-likc. Spicules- $\mathrm{fcw}$ fine, needle-like.

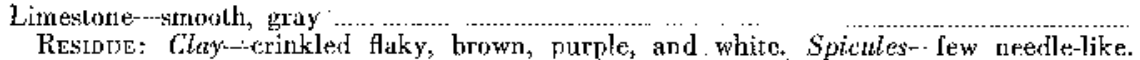

Iimestone-smooth, dove-gray. Chert-small amount grayish white $\ldots \ldots \ldots$ Residue: Chert-smooth, buff; fine granular, grayish, in part quartzose: Claycrinkled flaky, brown, Spicules-few very fine, ncedlclike.

Dolomite-extremoly finc, light gray, 80 percent. Limestone-smooth, gray, 20 percent $50-55$ Rusibue: Clay--sponge-like, lacy, ant crinkled flaky, gray. Spicules-fine, needle-like.

Dolomite-extroncly fine, light gray, 90 percent. Limestone-smooth, light gray, 10

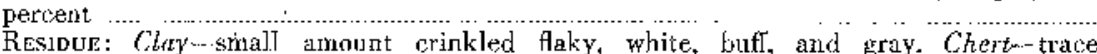
Residue:
halcedonic.

Limestone-smooth, light gray

Kesulve: Chert - frite granular, white, porous, small amount claurtzose trace prendooolitic: Quartz--few fine to very fine angular grains. Clay trace flaky.

Dolomite-extremejy fine, light huff, 90 percent. Linestone-smooth gray, 10 percent ${ }^{-\ldots-. .} 65-70$ Risusus: Sund wabandant, very finc, angular; fine to coarse, well rounded and frosted. Chert-chalcedonic, drusy in part. Clay-small amount sponge-like, lacy.

Dolomite-extremely fine, light gray, 50 percent. Limcstone-extremely fine to smooth,

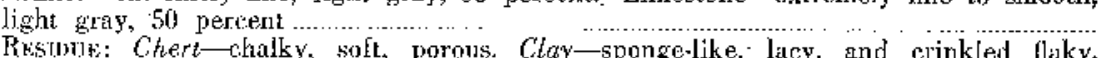
Resturit: Cher
white and bulf.

Limestone-smooth, light gray and gray

REstDue: Chert-small anount very rough, concretionary, white, Clay-small amount crinkled flaky, buff.

I imestone-smooth, very lisht gray

Resirue: Clay-crinkled flaky, whitc, some buff. Chert-small amount very ronghly concretionary, smonth white. Spicules-few extremely finc. 
Limestone-smooth, dove-gray

Resirue: Clay-crinkled flaky, light buff to white. Chert-trace smooth, light buff.

I.jnestone-smooth, light, slightly buff-gray. . . . . . . 90 - 95

Residov: Chay-crinkled flaky, and sponge-like buff-brown to gray. Shale-trace, smooth textured, gray.

Dolomite-extremely finc, light cream.

Residue; Clay-small amount sponge-like. Silt-trace.

Dolomite--extremely fine, very light cream

REsidne: Clay sponge-like, gray, in part lacy.

Limestone-smooth, gray

RFSTIUE: Clay-sponge-like to slightly compact, white; crinkled flaky, buf:. Siltsmall amount.

Dolomite-extremely fine, very light gray, 50 percent. Limestone-smooth, gray, 50 Rercent ${ }_{\text {Rimut }}$ Clay-crinkled flaky, brown. Silt-coarse, grating to very fine sand. Chert -fine granular, grayish, in roughly hotryoidal fragments.

Limestone-smooth, gray, 90 percent. Dolomite-extremely finc, very lisht cream, 10 percent - Chert-fine granular, slightly translucent-brownish gray. Clay-sponge-Jite grayish white.

Limestone : smoth, gray, 60 percent. Dolomite-extrenely fine, very light cream, 20

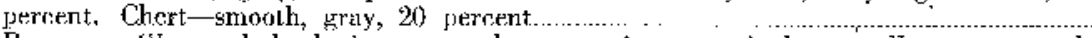

RESIUUE: Chert--thalcedonir, gray and maroon, in part spicular; smalt amount rough, fine granular, gray. Silt-small amount. Clay-amall amount crinkled flaky. Spicules - lew needlc-like.

Limestore -smooth, gray

Residis: Clay-crinkled llaky, brown and maroon. Chert-small, granular fragments, apparcntly fragments of silicified fossils and small concretions. Spicules-abundant needlelike, few with finely branching ends.

Iimestone-smooth, gray

Residue; Chert-smooth, in part slightly chalcedonic, in part porcelaneous, iraces psuedo-oolitic structure, some spicular, white to buff. Clay-flaky and sponge-like, Iight buff. 'Spicules-fine, needle-like.

Iimestone-5mooth, gray, in part with ineven, fragmenta]-appearing structure. Dolomite -trace very fine, light gray

Resinue: Chert-smooth, light bufl to white, spicular; chalky, hard; some grantar, white. Clay - sponge-likc, some llaky, white, buff and brown in part dolomoldic: Spicules -fine, nocdle-like.

Limestone-smooth, gray, in part maroon splotched, in part with indistinct, uneven R.trumere Chert-smooth, variegated powder-white and grayish chalcedonic, spicular R.FSInUk: Chert-smooth, variegated powder-white and grayish chalced
in part. Clay--sponge-like, maroon and buII. Spicules-few, needlc-like.

Limestone-smooth, gray

Restoue: Clay-erink]ed flaky, buff and white. Chert-chalky, soft, porous; trace roughly concretionary, chalccdonic. Spicules-few fine, nocdle-like. Sand-nlew fine frosted grains.

I.imestone-smooth, gray

Residus: Clay-crinklcd flaky, rust colored. Chert-small amount white, finely nodular, concretionary.

Limestone-smooth, gray ...

Resipue: Chert-fine granular, gray, scattered porosity. Clay-some sponge-3ike, Iight gray. Shale-grayish green, s].ightly waxy.

Limestone--smooth, gray, in part with indistinct fragmental strucfure

Restoue: Clay-sponge-like, white; some flaky; buff. Spicules-needle-like, few finely branching.

J.imestonc-smooth, gray

Restoue: Chert mooth, white to grayish white, in part slightly chalcedonic. Claysome flaky, pink. Fossil-small, silicified gastropod.

Limcstone- smooth, light gray, some pinkish maroon

Resipue: Cloy-fiaky, buff, pink, maroon, and white. Chert-small amount smooth, whitc. 
Iimestone-8mooth, dove-gray ....

Residue: Quartz-anhedral, granular to subhedra], drusy. Chert-small amount hard, chalky. Clay-flaky, bulf.

I.imestone - smooth, dove-gray. Dolomite-small amoant very fine, light gray......

Resioue: Chert-grayish white, chalcedonic, in part pseudo-oolitic; some soft, extremcly fine porous, chalky. Clay-flaky, greenish qray.

Limestone-smooth, gray, in part finely dolomitic.

Resinue: Chert-fine granular, brownish gray, oolitic, scattered fine dolomolds and porosity. Spicules-trace fune. needlc-like.

Dolomite---very fine, light gray. I,imestone-some smooth, gray, dolomitic

Residve: Quartz-anhedral, in. rough fragments with subhedral, drusy surfaces. Clay

--spongc-like, lacy, and very finely skelctal dolomoldic; sone flaky.

Dolomite-extremely fine, light bufl-gray, ${ }^{*} 80$ percent. Limestone-smooth, very light gray, 20 percent
Restous: Clay - sponge-like, flaky, and extremely fine skelelal, tragmental dolomoldie. Restous: Clay-sponge-like, laky, and extremely fine skelelal, tragmental dolomoldie.
Quartz-anhedrel, rough to nodular, and subhedral, drusy: Spicules-fine, needle-like.

Limestone-smooth, very light gray, 90 percent. Dolomite--.-extremely fine, light buff, 10

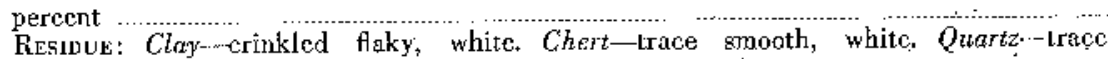

anhedral.

Limestone-smooth, light gray, 90 percent. Chert-smooth, light tan, 10 percent. Resinus: Chert-smooth, white and tan; fine granular, grayish; and finely laminated, $\tan$.

Limestonc-smooth, dove-gray Residue: Clay - trace fine, needlc-like.

Iimestone smooth, very light gray..

R.ssidus: Clay-flaky, grayish white and pink. Chert--small amount chalcedonic. pscudo-oolitic. Spicules-very fine, needle-like.

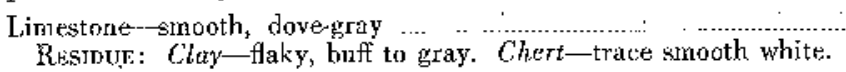

Limestone-smooth, dove-gray

Ristdes: Chert-smooth, white to fine granular porcelaneous; some fine granular, slightly trantlucent-gray, scattered porosity. Spiculds-few extremely fine.

Limestone-smooth, gray, 50 percent. Dolomite-extremcly fine, light, slightly buff-gray, 50 percent $C l a y-f$ laky, light green and white; some sponge-like, whitc. Silt-very fine. Kesivur: Clay-Alaky, light green and white; some spong
and-lew finc, frosted grains. Spicules-fine, needle-like.

Limestonc-smooth, dove gray. Chert-some smooth grayish white

Reswus: Chert-snooth, grayish, white, and chalcedonic: Quartz-rough, gramular, some lacy. Clay-flaky, greenish, bult, and white. Silt-small amount very fine. Spicules -fine, needle-like.

Limestone-smooth, Jight gray. Chert-some smooth white

RISIDUE: Chert-smooth, buff to whitc; granular, transclucent-gray, quarlzose, porous;

small amount hard, chalky, biff. Clay-flaky, brown to greenish. Sand-fine, rounded,

frosted. Silt-small amount very fine.

Iimestone-smooth, light gray, 80 percent. Dolomite-extremely fine, light gray, 20 Russmuk: Clay-flaky, brown to gray. Sand-fine to very fine, ronnded, frosted. Silt small amount.

Limestone-smooth, light gray. Dolomite-small amount finc, light gray Resinue: Quartz-anhedral, very rough, porous. Clay-flaky, gray and greenish. Sitt - coarse quartz.

Jimestone-smooth, light gray, trace finely dolomitic. RFsidDe: Clay-flaky, light greenish, some pink to maroon. Silt-very fine.

Limestone-8mooth, light gray, some linely dolomitic .................
Residue: Clay-faky, light greenish. Silt-coarse to very finc.

olomite-extremely fine to very line, light buff and light pinkish gray. Limestone-trace light gray, dolomitic.

Resmoe: Quartz-subhedral, in irregular, porous masses. Chert-chalky, soft, white. Sand-fine to very fine, lightly frosted. Silt-very fine. Clay-white, finely fragmenta? dolomoldic. 
Dolomite-very fine, light gray.

Residue: Clay-white, very fine fragmental and skeletal dolomoldic. Silt-very fine.

Quartz-subhedral, in rough, irregular fragments.

Limestone--.smooth, light uray.

Resinur: Clay-crinkled flaky, white, some pink. Sand-fine to medium coarsc, well rounded, lighlly frosted. Chert-small amount sxiooth, white.

Dolomite-extremely fine, buff, some light uray.

Resines: Quartz-subhedral, as loose grains and in very rough, irregular fragments. Clay-brown to gray, extrenely fine dolomoldic in extremely fine framental and skeletal dolomoldic fragments.

Dolomite-very fine to fine, light grây, in part with scattered sand grains.

ResinJE: Sand-coarse to tine, rounded, frosted, some showing secondary growth. Clay —white and brown, finely fragmental dolomoldic: Silt-small amount.

Limestont-smooth, light gray. Chert-trace smooth, grayish white and brown

RistuUt: Chert --smooth, porcelancous and ordinary, white to brown; small amount soft chalky, Clay-sponge-like and flaky, white and brown. Quartz-few medium stubby, euhedral prisms,

Limestone-smooth, dove:uray, 90 percent. Dolomite-very fine, buff, 10 peroent

Resious: .Quartz-snhedral and subhedral, in very rough, porous fragments. Claybrown to white, spongc-like, in part lacy, in part finely fragmental and skeletal dolo. moldie, some flaky.

Dolomite-extremely fine to very fine, brown to light gray

RestoUt: Quartz-milky, granular, anhedral, in extremely rough, irregular flakes and massos, with a few drusy surfaces. Clay-brown, extremely fine fragmental.

Dolomite-cxtremely fine, light buff-gray, 90 percent. Chert-smooth., white, oolitic, 10 percent

ResidIs: Chert-smooth, white, oolitic, in part chalcedonic, containing scattered sand grains; fine granulax, translucent-grayish, extremely fine dolomoldic. Sand-few coarse, rounded, frosted grains.

Dolomite-very fine, gray. Limestone-small amount, smooth, very light gray

REsinUe: Claty-buff, finely framental skeletal dolomoldis, Chert-trace fine granular, white nodular.

Limestone-smooth, grayish white, 50 percent. Dolomite-very fine, gray, 50 percent.......315-320 Kesidir: Clay-buif-brown, finely ske]etal dolomoltir, and very finely frarmental. Chert-trace smooth white.

Dolomite-very fine, buli-gray, in part highly arenaceous, 70 percent. Limestone-smoolh,

gray to maroon mottled, in part arcnaceous, 30 percent... . . ...................................

Restouk: Sand-abundant, coarse to very fine, well rounded, very finely frosted, some grains Jightly colored by maroon fillings in frosting. Clay-small amount light. buff, sponge-like, in part Iacy.

Gorman formation, 325-745 feet-

Limestone-smooth, light gray, in jart doTomitic.

Residte: Clay-gray, llaky, Fossil-fragments silicified brachiopod.

Limestone-msmooth, dove-gray, with few embedded, frosted sand grains

Residue; Sand-coarse to fine, rounded, very lightly frosted. Clay-greenish gray, Ilaky.

Ijmestone-smooth, light gray.....

Residue: Clay-small amount flaky, white, light buf, and pink.

Limestone-smooth, very light gray

Risuve: Clay-flaky, white to slightly greenish, Chert-trace fine granular, slightly translucent, porous.

Limestonc-smooth, gray

Fisubue: Clay-flaky, gray, slightly grandilar. Quarlz-very delicately lacy Iragments.

Limestone-smooth, dove-gray

Resioue: Clay-flaky, buft.

Limestone- smooth, light oray Residve: Clay-crinkled flaky, buif, gray, and maroon.

Limestone - smooth, light tan-gray, 80 percent. Dolomite- fine, gray, 20 percent_-_..... $360-365$ Restrue: Clay-erinkled flaky, yellowish brown.

Limestone-smooth, light gray finely splotched with brown $365-370$ Residue: Clay-crinkled Iliky, white to buff. Chert-trace chatsedonic. 
Dolomite-very fine, light buff-gray

liesmuk: Chert -smooth, white; trace hard chalky; race fine granular, white. Clay--

buff, very finely fragmental, and brown, skeletal dolomoldic.

Dolomite-very fine, light gray, buff, and brown.

Resinue: Clay-buI, extremely fine fragmental. Chert-trace fine granular, dolomoldic, drusy. Sand-few fine to medium, rounded lightly frosted grains.

Dolomite-very fine to extremely finc, light buff-gray, 90 percent. Chert-8mooth, grayish white, in part oolitic, 10 percent.......................................................... Rssinve: Chert-ordinary smooth and porcelameous, white, in part indistinctly

Dolomite-very fine, light gray, 50 percent. Limestone-smooth, very light gray, 50 percent ..... Sil - extremely fine. (lay-small amount flaky, greenish.

Limcstone-smooth, very light gray.

Resibue: Clay-flaky, slightly grecuish white, and buIT.

I,imestone-sinooth, dovc-gray. Dolomite-small amount very fine, bufl-gray Restoue: Clay-flaky, greenish brown.

Limestone-smooth, gray Ressove: Chert-chalky, hard; smooth, while, trace oolitic. Clay-sponge-like, white,

flaky, greenish brown. Silt - small amount.

Limestone-smooth, dove-gray

Residue: Clay-flaky, gray and buff. Sand-small amount fine, rounded, very lightly

frosted. Chert-trace smooth, white, finely oolitic.

Limestone-tmooth, light gray. Dolomite-smal]. amount fine, light gray.

Rrsidise: Clay-mllaky, whilish gray. Quartz-trace drusy.

Dolomite-fine to medium fine, gray...

Resubus: Clay-flaky, buff to gray. Sand-fine to very fine, rounded, very lightly

frosted. Silt-wcourse to very fine. Chert-trace smooth, white.

Limestone-Smooth gray in part dolomitic, 80 percent. Dolomite-extremely fine; buff_..-420-425 Resivú: Clay-flaky white, and extremely fine fragmental, brown.

Jiniestone-smooth, gray Resinos: Chert-smooth, white, in part with very fincly focculent structure. Sand-small amount finc, rounded, frosted.

Limestone--smooth, very light gray. .....

Rrsibne: Clay-faky, slightly greenish brown, and gray, Silt-small amount coarse.

Sand-few fine, slightly frosted grains.

Limestone-smooth, gray, in part indistinct, finely fragmentał strui:ture............................ 435-440) Rrsinde; Sand-very fine to medium, rounded, frosted. Silt-cosrse to very line.

Clay-flaky, brown to buff.

Limestone-smooth, light gray, 50 percent. Dolomitc-very fine, light. gray, 50 percent--.-440-445 Resinde: Clay small amount, extrémely fine, tragmental.

Dolomite-very fine, light gray
REsioue: Chert $\rightarrow$ mooth to slightly chalky, very finely scattered to abundant dolomol-

Residue: Chert mooth to slightly chalky, very finely
ir; some very fine granular white, very hinely dolonoldic.

Limestone-smooth, gray

Resid amount fine, rounded, lightly frosted. Sill-coarse.

Limestone-smooth, gray, 70 percent. Dolomite-fine, gray 20 percent. Chert-smooth,

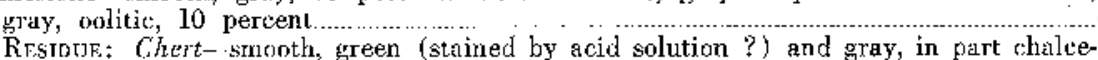
donic, highly oolitic and partly arenaceous; line granular, very finely porous, white. Sand-simall amount finc, rounded, frosted.

Limestone-sinooth, light gray, 50 percent. Dolomite-extromely fine, ljght gray...........460-465 Rrsidus: Clay-crinkled flaky, greenish gray and white. Chert-chalky, soli, grayish white.

Dolmite... extremely fine, light gray.

Rrsidij: Clay-irall amount sponge-like, gray. Chert-small anount smooth, white.

Dolonite-exlremely fine, lirht gray........

Resivie: Silt-fine. Sand-few fine, frosted grains.'

Dolomite-extrcmcly finc, light gray, some buff.

Resinue: Silt - fine to coarse, angular, loose and in soft, argillaceots aggrerates. Sand

-very fine, rounded, very slightly frosted. 
Limestone-smooth, very light gray. Dolomite-small amount very fine, buff

Residue: Chert mooth, gray to whitc, in part fine to medium, oolitic, parl pseudooolitic, contains scattered sand grains, has scattered porosity. Sand-very fine to medium, rounded, very slightly frosted. Clay-crinkled, greenish white.

Limestone-smooth, very light gxay......

Resiove: Clay-crinkled flaky, white, gray, and buil. Sand-line to very fine, well roundet, very slightly frostet. Silt-simall anount. Spixules-fine, needle-like. Shaletrace gray, slightly waxy.

Limestone-smooth, dove-gray

REsIDeE: Clay-crinkled flaky, buff to gray. Sand-very fine, slightly frosted.

Jimestone-smooth, light gray

Kesivue: Clay-crinkled laky, white, some greenish gray, some muddy gray. Sandvery fine, very slightly frosted.

Limestone-smooth, light gray.

"Residuv: Clay-crinkled flaky, slightly greenish buf, some white. Sand-small amount very fine, very slightly frosted.

Limestone-smoolh, light gray.

RTSIDve: CIay-crinkled flaky, slightly greenish buff, brown, some white. Silt-very small amount.

Limestone-smooth, very light gray

Rrsidus: Chert-chalky, white, porous; smooth, white. Clay-flaky, grcenish gray, some whitc. Sand-mall amount very hime, slightly frosted.

Limestone-smooth, dove-gray

Restuve: Clay-erinkled flaky, white, greenish gray, buf. Silt-smal] amount coarse. Sand-very simall amount very fine, very slightly frosted.

I.imestone-smooth, very light gray......

Residue: Clay-crinkled flaky, light gray, greenish gray, and buft, in part slightly silty. Silt-small amount very fine.

Limcstone-smooth, very light gray.

REsidue: Clay-crinkled flaky, white to slightly greenish.

Jimestono - smooth, dove-gray, in part arenacceous, 90 percent. Chert-smootb, light bufl,

10 percent Chert-smooth, white to very light buff; chalky, soft, white. Sand-coarse

KessbuE: Chert-smooth, white to very light buff; chalky, soft, white. Sand-coarse
to fine, rounded, frosted. Clay-flaky, grcenish gray and white, very linely fragmental.

Limestone-smooth, light gray.

Resioue: Clay-llaky, white to buff. Sand-well sorted, fine, rounded, listicly frosted.

Limestone-smooth, light rray

Resious: Clay-flaky, slightly greenish, light gray, bpff. Sand-vcry fine, slightly

frosted, grading to coarse silt. Silt -small amount coarse.

Limestone-smooth, very light gray

Residue: Chert-gradational between chalky and fine granular, hard, white, finely porous; fine granular, translucenl-gray, in part porous, and in part pscudo-oolitic.

Limestone-smooth, Tight gray, in part indistincl fragmental struclure.

Residue: Clay-flaky and sponge-like, greenish buff and white:

fimestone-smoolh, very light gray.

Resivue: Clay-rinkled flaky, brown to buff, some white. Chert-small amount chalky. Silt-very fine.

Limestone-smooth, light gray, some maroon staining

Restouk: Clay-llaky, greenish buff and salmon-pink. Silt-smell amount very fine.

Chert-trace smoky, cha]cedonic.

Linestone-smooth, light gray.

Resmov: $C l a y-$ small amount flaky, buff. Silt - -irace very fine.

Limestone-smooth, light gray.

REsiDUE: Clay-crinkled flaky, greenish buff to brown, some white.

Limestone-smooth light gray, with fow enbedded sand yrains.

Restotus: Sand-coarse to fine, rounded to subrounded, lightly frosted. Clay-crinkled

flaky, brown to buif.

Limestone-m-smooth, light gray. Chert-m-small amount whitc, calcarcous...

Residur: Chert-chalky, white, finely porous, some gradational to fine granu]ar; fine granular white; smooth, white. Clay-crinkled flaky, greenish gray to buff.

Limestone-smooth, light gray, 50 percent. Dolomitc-coarge light gray, 50 percent..... 585-590

Reswue: Chert-very small amount gray chalcedonic. Clay-trace laky white. 


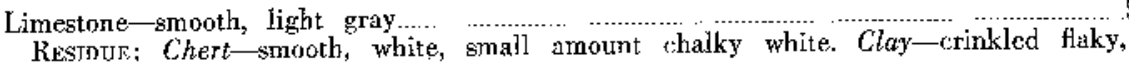
greenish buff.

Limestone-smooth, light gray, 90 percent. Chert-smooth, white, 10 percent................595-600

REsinue: Chert-smooth, variegated. white and grayish white, with trace druse.

Clay-small amount flaky, grecnish gray.

Limestone-smooth, very light gray....

Kestour: Clay-crinkled flaky, white and huf:

Limestone-smaoth, light gray, 50 percent. Dolomite-extremely fine, light gray, 50 percent ..........................................

Resilok: Chay white, gray, some brown.

Dolomite-w,extremely fine, gray

Resinje; Clay-sponge-like, white. Silt-fine to very fine.

Dolomite-cxtremely finc, some fine, light gray, 60 percent. I.imestone-smooth, light. gray, 40 percent. Cherl-trace; grayish white ..............................................615-620 Restue: Cherl-smooth, gray to grayish white, some finely porous. Clay-flaky, grayish white.

Limestone-c-stnooth, light gray. Dolomite-smal]. amount medium, light gray.

Residus: 'Clay-flaky and fimely fragmental, in port dolomoldic, slightly grayish white.

Chert-trace smooth, whitc. Silt-small amount very fine.

Limestone-smooth, dove-gray
Resivus: Chert-snooth, white; trace chalky. Clay-flaky, light green and brown. Resivus: Chert-rsing
Silt - fine to very fine.

Limestone-5mooth, light gray.

Resweve: Clay-spongc-like and flaky, brown and white, in part finely fragrental.

Chert-trace smooth, white. Silt-very fine. Sand-few fine, frosted grains. Limestone-smooth, light gray. some light green, slightly waxy.

Bolomite very fine to extremely fine, lisht gray.

Rrsinue: Clay-finely ragmental, skeletal dolomoldic, white. Silt-small amount vory fine, Sand-few very fine grains.

Dolomite-extremely fine, very light gray

Rrsinte: Sand-very fine, slightly rounded and frosted to extrcmely fine, angular.

Dolonitc-extremely fine to very fine, light gray, some buft . ..................................650-655 R.Esidue: Sand-very fine, slightly rounded and frosted to extremely fine Claysponge-like, white and buff, slightly dolomoldic:

Dolonite-extremely line, buff; and fine, light gray................................................

Resmok: Sand-coarse, wefl rounded to fine, subromded, frosted, free and in argil-
aceous clustcrs. Silt-small amount. Clay---small amount faky, brown and greenish laceous clustcrs. Silt-small

Limestone-very smaoth, white, 80 , percent. Chert-smoolh and ehalky white, 20 percent....660-665 Residue: Chert-chalky, hard to very soft; swooth, white.

Dolonite-extremely fine, light buff-gray; and medium fine, gray

Rrsipue: Clay-huff, brown, and white, finely fragmental akeletal dolomoldic and

flaky, porous. Sand-small amount, very slightly frosted. Silt-usmall amount.

Dolomitc-extremely fine to fine, light buff-gray.

Residos: Clay slightly grcenish, light buff to brown, finely skelctal dolomoldic, some

taky. Sand-metium to fine, subrounded, lightly frosted. Sitt-small amount.

Limestone-smooth, light gray, 50 percent. Dolomite-extremely fine to fine, huff-gray,

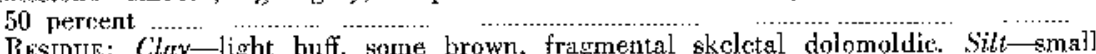
Restnus: Clay-light bint, whoce smooth, white.

Lintestonc-smooth, light gray, in part arenaccous. Chert--.some smooth, gray.

Resmuv: Chert mooth, white to grayish, some indistinctly mottled, some with embedded sand grains; small amount chalky. Sand-coarse, well rounded to very fine, angular, frosted. Silt-small anount coarse.

Limestone-smooth, light gray.......

RESIDUR: Chert-smooth, white to light tan; small amonint very fine granular, light tan; small amount chalky, white. Sand-coarse to very fine, subrounded, frosted. Silt"coarse to fine. Clay-flaky and finely fragmental, greenish buff and white. 
Limestono-smooth, very light gray

Kesidur: Clay-flaky, grayish white, some brown. Sult-moarse to very fine. Sandfew medium rounded, frosted grains.

Jimestonc-smoolh, light gray.

Residur: Clay-flaky, light greenish gray, some buil and brown., Sarkd-finte to very fine, frosted. Silt -coarse to very fine.

Limestone-smooth, gray, some maroon, 80 percent. Chert-smooth, gray, 00]itic, 20 percent ... Chert-smooth, gray, oolitic, few embedded sund graing; smooth, white, Clay -sponge-like and llaky, greenish white and brown, Sand-small amoint fino, rounded, frosted. Silt-small amount coarse to fine.

Limestone-smooth, light gray, in part with indistinct fragmental structure, 60 percent.

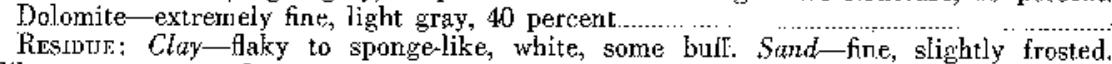

Silt-coarse to very fine.

Dolomite-extremely fine, grayish white

Resides: Silt-fine, abundant. Chert-chalky, white. Clay--small amount very delicatcly sponge-like.

Dolomito-extremely fine, very light buff, and grayish white

Resioue: Silt-abundent, coarse to fine, slightly argillaceous, chicfly loose, few porous, silty fragments.

Dolomite-fine to extremely, fine, light gray, small annount pink

Residue: Clay-white, skeletal and finely fragmental dolomoldic. Chert-nevery soft, chalky, porous and dolomoldic, trace smooth, gray, oolitic. Sand-small amount very fine, frosted. Silt-trace.

Dolomite-very fine to extremely fine, very light gray.

Residue: Chert-soft, chalky, grayish white, finely dolomoldic. Clay-ilaky, s]ightly cream-whitc, fincly dolomoldic in part. Sand small amount very fine, sightly frosted. Silt-coarse.

Dotomite-extremely fine to very fine, grayish white..

Resinur: Sand-coarse, well rounded to very fine; subrounded, frosted. Silt-coarse to very fine. Clay-small amount sponge-Iike,-white.

Jolomite-extremely fine to very fine, light gray, in part sandy.

Røsivue: $S$ and-coarse to very fine, rounded, frosted, with well developed sccondary frowth, showing some well-terminated quartz crystals. Silt - small amount very fine.

Limestone-smooth, light gray.

Restove: Clay-sponge-like and flaky, slightly greenish, light gray. Sand-cosrse to fine, weJl rounded and frosted.

\section{Syićewood Creek Sectyon, San Saba Codnty, Texas}

\section{Gorman formation, $0-57$ feet-}

Jolomite-extremely fine to very finc, light, very slightly buff, 60 percent. I.imestone-w extremely fine, grayish white, 30 percent

Residue: Silt-coarse to fine. Clay-in very fine particles, Sand-few very fine grains.

Chert - trace smooth, white, in part chalcedonic.

Dolomite--extremely fine, light, very sIightly buff; and very fine, very light gray

Residue: Clay-extremely fine, fragmental dolomolds. Silt-mall amount loose.

Dolomite-extremely fine, light buff; and very fine, very light gray with scattercd pinkish stains. Chert-trace ordinary to porcelaneous smooth

R.esinue: Chert-smooth, white, approaching porcelaneous. Clay-sponge-like, ex. tremely fine to very fine skeletal dolomoldic, and in very fine particles. Silt-small smount loose,

Ilolomite-extrcmely fine, very light gray, with irrogular, light buff coloration

Rrsidue: Chert-chalky, argillaceous, extremely fine, abundant to skcletal dolomoldic. Clay-sponge-like, extremely fine skeletal dolomoldic. Sand-very fine, rounded, frosted, loose, and in small aggregates. Sult-Joose.

Dolomite-very fine, very light gray. Chert-small amount sniooth white, in part finely dolomitic; trace extremely fine granular chert.

REsTDUE: Chert-smooth, white, in part silty; very fine granular, very slightly translucent. Clay-rsponge-like, extremely fine dolomoldic, and in very fine particles. Silttrace white siltstone. 
DoTomite--extremcly fine to very fine, very light yray ................ . ......................... 25-30

Resinur: Clay-sponge-fike and flaky, fincly dolomoldic. Sand-very fine, lightly frosted. Silt-loose.

Dolomile-extremely fine, unevenly light buff colored, 50 percent; very finc to fine,

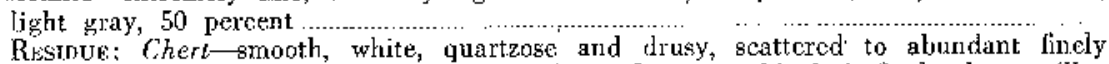
RESinUe: Chert smooth, white, quartzose and drusy, scattcred to abundant hinely
dolomoldic; chalky, white, scattered dolomoldic. Quartz subhedral, finely drusy. Cilay -sponge-like, extremely fine to vcry fine skeletal dolomoldic. Silt--loose.

Dolomite-extremely fine, grayish white, in part with embedded, very fine to finc

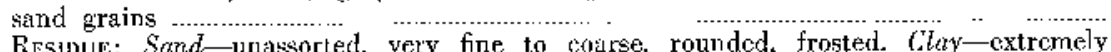
Residue: Sand-unassorted, very fine to to
ne fragmental skelctal dolomoldic. Silt-loose.

Dokomite-extremely fine, Jight gray, Chert-small amount smooth, gray, in part with

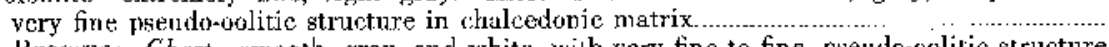
Resives: Chert-smooth, gray, and white, wilh very finc to fine, pseudo-oolitic structure in chalcedonic matrix; small amount cxtremely fine giranular, gray, pseuto-oolitic. Silt -loose.

Dolomite-extremely fine, very light gray.

Resipus: Chert-ordinary smooth, white. Sand-few very fine, lightly frosted grains. Sift-small amount loose. Clay-few flakes.

Dolomite-very fine, light buff-gray. Chert-smalt amount smooth, grayish white and finely banded

Residue: Chert - smooth, ordinary and porcelaneous, white with some gray banding, sparingly quartzose; small amount chalky, skeletal dolomoldic. Quartz-small. amount suluhedral, finely drusy. Sand-very fine to coarse, rounded, frosted. Clay mponge-like, very fine [ragmental skeleta] dolomoldic. Sitt suall amount loose.

Tanyard formation, Staendelach membcr, 57-460 feet-

Dolomite-very fine to oxtremely fine, light gray with uneven, light buff coloration

Rustous: Chert-smooth, white, very finely abundant dolomoldic; extremely fine granular, slightly transiucent, finely abundant dolomoldic, in part quartzose and drusy. Quartz-subhedral, finely drusy. Clay-sponge-Jike, very finely Iragmental skeletal dolomoldic. Silt-very small. amount loose.

I.imestone-smooth, dove-gray, in part with fine, indistinct pellet structure. Dolomitetrace fine, gray
Rusluut: Clay-flaky, white, few fine dolomolds. Sand-few very fine, frostcd grains. Chert--trace botryoidal chalcedonis:

Jimestone-smooth grayish white and dove-gray, 85 percent. Chert-smooth, bluish white and trace porcelaneous, 15 percent............................................. Resiouz: Chert smooth, chul

Limestone-smooth, dove-gray, in part with indistinct fragmental structure. Chert-small amount smooth, bluish white, chalcedonic, with few drusy surfaccs............................. $70-75$ Residue: Chert-chalcedonic, quartzose, in part drusy, with trace very fmely banded. Clay-flaky, white and pink staincd.

Limestone-extremely fine, dove-gray. Chert-small amount extremely 'fine granular and chalcedonic
Resivuz: Chert monoth, white to shalcedonic, in part with very rough and porous RESIVUe: Chert smooth, white to chalcedonic, in part with very rough and porous
contact surlaces; small amount extremely fine granular. Clay-sponge-like and flaky, white.

Limestone-extremely fine to smooth, dove-trray, in part slightly dolomitic, and in part with indistinct fragmental structure. Chert-small amount snoouth and some extremely fine granular, white to grayish white.......

Residue: Chert - smooth, chalcodonic to ordinary, white, in. part pseudo-oolitic; small amount extremely fine granular. Ctay-sponge-like and flaky, white and cream colorcd. Limestone-extremely fine, very light gray, in part siliceous. Residue: Chert-chalky, white, extremely fine porous, soft. Clay-sponge-like ant flaky, whîte.

Limestone-extremely fure, very Jight gray, 50 percent. Dolomite-coarse, very light gray,

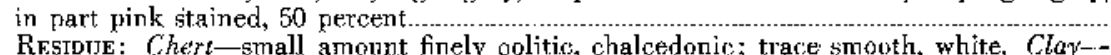
REsidiJe: Chert-small amon
finely flaky. Claucorte-irace.

Limestone-extremely finc, slightly grayish white, in part coarsely dolomitic

Risidue: $C l a y-$ mall amount fincly fragmental flaky. 
Limestone-extromely fine, very light gray. Chert-8mall amount smooth, white to gray....100-105 Resinus: Chert -imooth, white and chalcedonic. Clay-sponge-like and fiaky, white.

Limestonc-cxtremely fine to smooth, very light gray. Dolomite-trace medium grained,

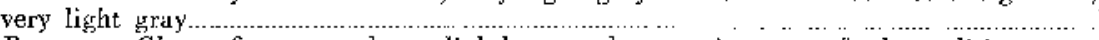
R.s.sidue: Chert-fine granular, slightly translucent, in part finely oolitic, trace oomoldic. Shale-waxy, light green, in fine fragments.

I.imestone-extrcrely fine, light gray. Resibue: + Chen-very small amount white and chalcedonic. Silt-small amount angujar grains, possibly feldspar.

Limestone exiremely fine to smooth, very light gray

RESIDUE: Chert-smooth to extremely fine, white to gray, in sharp contact with limestone, but with same texture as limestone.

Iimestone-cxtremely fine, very light gray, in part containing dolomitc rbombs. Dolomite, -small amount medium coarse, grayish white. Chert-some extremely fine granular,

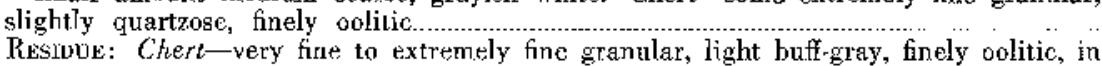
part quartzose; smooth, white, in part finely oolitic; chalcedonic, fmely oolitic. Claysponge-like and flaky, white. Quartz-small amount subhcdral grains.

Limestone-extremely fine, very light gray

Resinos: Cilay-sponge-like and flaky, Chert-small amount sott, white, chalky.

Limestone-extremely fine, white, in part medium to coarsely dolomiti:

Residue: Clay-asponge-like, white, in finc fragments. Chert-small amount fincly

botryoidal, smooth, white; trace soft, chalky.

Limestone-mextremely fine, white, in part medium to coarscly dolomilic. Residur: Clay-spongc-like and flaky, white, in part with traces of oomolds.

Limestone extremely fine, very Jight gray, in part coarscly dolomitie.

REsidin: Clay-small amount flaky, white, some buff. Chert-trace white, hotryoida],

Limestone-extremely fire to smooth, grayish whitc

REsidus: Clay-sponge-like and flaky, white. Chertw-sinall amount smooth, white, to shalcedonjc.

limestone-extremely fine, grayish white, slightly dolomitic. Chert-small amount extremely fine granular, gray, oolitic, very slightly dolomitic, with the dolomite rhombs and aggregates interrupting the oolitic structure

Rrsinue: Chert-extremely fine granular, grayish, slightly transclucent, fincly oolitic,

fow scattered dolomolds. Clay-sponge-like, white.

Dolomite-medium to coarse, grayish white.

REsidue: Clay-flaky, small amount sponge-jike, white.

Dolomite-medium, grayish white, porous, 50 percent. Limestone-extremely fine, grayish whitc, 50 percent... Residue missing.

Dolomite-medium coarsc, very light graly. Chert -..sma]l anount, very fine granular,

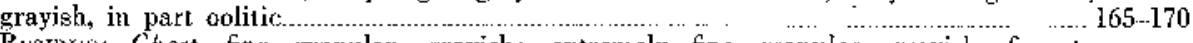
Resnue: Chert--fine granular, grayish; cxtremely fine granular, grayish, fine to medium oolitic. Clay-sponge-like, grayish white.

Dolomite-mecium, light bufl-gray. Chert-some smootle to extremely fine granular, grayish white, very sparingly dolomitic ... Kesivue: Chert--smooth to extremely fine granular, grayish, with soattered patehes of chaledonic. Clay-sponge-like, white to buff stained, dolomoldic.

Dolomite-coarse to medium, lighit gray, porous. Chert-small anouml variegated smooth

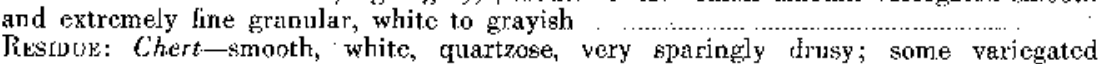
Resibus: Chert-smooth, white, quartzose, very sparing
mooth to extremely fine granular. Clay-small amount flaky.

Dolomitc-medium coarse, grayish and slightly pinkish white. Linestone-small amount.

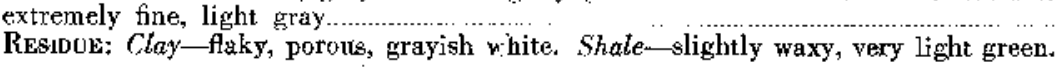

Limestone-smooth, very light gray, in frart intermixcd with coarse dolomite. Dolomitecoarsc, very light uray, in part intermixed with smooth limestone.

Resibue: Clay-fiaky, buff stained; small amoust sponge-like, white. Chert-small amount smooth, grayish white.

Iimestone-smooth, very light gray, in part coarsely dolomitic Risious: Clay-flaky, very slightly greenish. 
I.imestone-extremely fine, very light gray, with veinlets of pinkish dolomitc. Dotomitesome medium to coarse, very light wray .................................................................. 195-200

Residue: Clay small amount flaky, white. Chert-trace smooth, white.

Dolomite-medium coarse, very light gray with stight rose coloration.........................200-205
Residoue: Clay-small amount fragmental skcletal dolomoldic, some flaky. Chertsmall amount rough, nodular, smooth white.

Dolonite-coarse, yery light gray

Rrsidie: Clay-small amount sponge-like, lacy; trace fragmental skeletal dolomoldic.

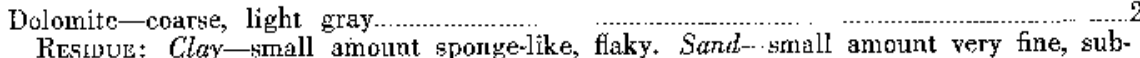
angular, very lightly frosted.

Dolomite-medium coarsc, very light gray, 80 percent. Limestonc-cxtremely fine, very

light gray, 10 percent. Chert-smooth, brown, 10 percent_-_._.

REsinte: Chert-smooth, brown, small amount smooth, white. Claynsmall amount sponge-like, huff-white. Sand-small atrount very fine, angular.

Dotomite coarse, light wray und gray

Residue: Clay-small. amount sponge-like, white and llaky, brown. Sand-lrace very fine.

Dolnmile-medizu, slightly brownish gray. Chert--. small amount snooth, grayish white .. 225-230

Residue: Chert-ordinary smooth and porcelaneous, whitc. Spicules-few very fine, nccdle-like.

Dolomile-waricgated texture fine to coarsc, slight]y buff-gray....

Residie: Clay-small amoun $\ddagger$ sponge-like, white. Chert-small amount chalk textured, whitc; trace chalcedonic. Spicules-numerows very fine, needle-like.

Dolomite-medium coarse and medium fine, gray, in part porous. Chert-small amount smooth and porcelaneous, white, in part oolitic.................................................. .

Rusinus: Chert-ordinary white, in part quartzose and drusy; porcelaneous, in part oolitic and pscudo-oolitic. Quartz--small amount subhedral. Ooliths-few free. Spicules - few very fine, needle-like.

Dolornite-medium fine, gray, slightly porous

Resides: Clay-small amonnt 'fragmental, skeletal dolomoldic. Chert-trace chajcedonic. Spicules-ufew needlenlike.

Dolomitc-mcdium fine, gray. Cher--small amount smooth, white to gray, in part

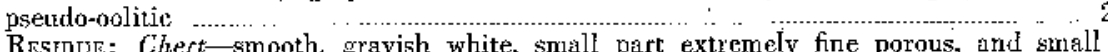
Rissoue: Chert - smooth, grayish white, small part extreme

DoJomite-medium to coarse, gray. Chert-rrace smooth, white,

Resmue: Chert-smooth, white, in part indistinctly pseudo-oolitic; chalky, creamwhite, scatteringly to ałundanuly dolomoldic. Clay-sponge--]ike and [ragmental do] omo]. dic, cream-whitc.

Dolomite--medium to fine, gray. Chert-5mall amount smooth, grayish white with very finely flucculent structure white to grayish white, in part with poorly developed doloResidue: Chert-smooth, white to grayish white, in prant with poorly developed dolo-
molds, in part finely oolitic, some roughly porous and finely drusy. Clay-small amount sponge-like, dolomoldic.

Dolomite-coarse, gray, very compact.

Residve: Clay sponge-like, highly porous, white and luff. Chertm ngranular, very slightly translucent and buff, roughly fragmental, sparingly dolomoldic, with some very. fine druse; small amount chalky, white porous.

Dolomite-coarse, light gray, pery compact.

Resibue: Chert-granular, gray to buff-gray, in part sightly porous and sparingly dolomoldic. Silt-remarkably clear tuartz, possibly chemical in origin.

Dolomite-- coarse to medium, gray.

Resintre: Chert-chalky, white, in very rough, porouta fragments, soft to hard; trace chalcedonic. Clay sponge-like, while, in very fine, flufly fragments.

Dolomitc-medium coarse, gray, 80 percent. Chert-very fine granular gray, 20 percent 275-280

lissivus: Chert-granular, light, very glightly translucent with some gray, in part slirthtly porous; small amount drusy. Quartz-very fine, angular grains, possibly ahemical in origin.

Dolomite-medium coarse, light gray, with scattered pink coloration.

REsuU: Chert-fine gramular, white, abundant to skeletal dolomoldic, drusy. Quartz - subhodral, drusy. Clay-skcletal. dolomoldic. 
Dolomite-medium coarse, light gray: Limestone-trace extremely fine, light gray

RFsinue: Chert-fine granular, white, abundant to skelctal dolomoldic, quartzose, drusy; extremely line sranular, white to bulf stained. Quartz-..anhedral, clear and subhedra], coarsely drusy. Clay-small amount skeletal dolomoldic.

Dolomite--.medium fine to fine, light gray, 90 percent. Chert-smooth and very fine

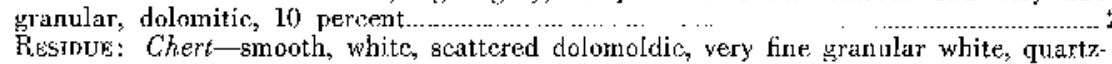
ose and drusy, scattered dolomolidic. Quartz-subhedra], drusy.

IYolomite-medium, very light gray..

Resides: Quartz- small amount anhedral, finely granu].ar, some subhedral, drusy. Clay -small amount fragmental dolomoldic.

Dolomite-medium, very light gray.

Restous: Clay-fragmental, skclctal dolomoldic. Chert-trace fine granular, pink to whitc.

Dolomite-medium coarse, lighe gray. Chertw small amount granular, whitc, slightly

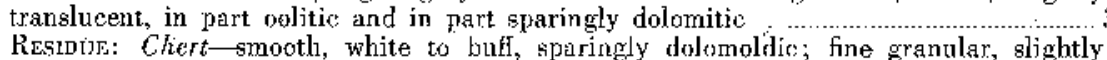
Residies: Chert $\rightarrow$ mooth, white to buff, sparingly dolomoldic; fine granular, slightly
ranslucent. in part oolitit, in part abundant dolomoldje. Quartz subhedral, drusy, dolonoldi:

Dolomite-medinn fane, light gray and some pink coloration. Chert-small amount granular, grayish white, oolitic,

Resivoe: Chert-fine, granular, grayish white, fine to medium oolitis, lew dolomoldic laagments. Quartz-subhedral, drusy, in part dolomoldic. Clay-tragmental skeletaI dolomoldic.

Dolomite-medium, light gray, sparingly cherty

RFSIUIE: Chert snooth, white, scattered dolomoldic, very fine granular, abundant to skeletal dolonoldic, in part finely drusy; cbalky, white to grayish. Quartz-small amount subhedral, drusy. Clay-finely fragmental dolomoldic.

Dolomite-fine to medium fine, slightly buff-gray, 90 pcrcent. Chert-grayish white, varie-

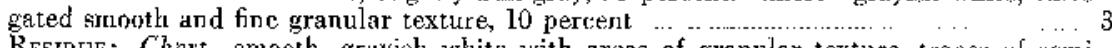

Residiz:; Chert smooth, grayish white with areas of granudar tcxture, traces of semispherical concrctionary structire, small amount finely drusy, small anount very finely oolitic. Quartz-subhedral grains.

Dolomile--fine, slightly buff-gray. Chert-small amolnt granular, grayish white, oolitic....325-330

Residus: Chert - fine granular, grayish white, fincly oolicic, few scattered dolomolds, slightly drusy. Clatyn...sponge-like, white and buff, finely fragmental.

Dolomite-medium fine, gray. Chert-traces fine granular

Resmes: Chert-granular, white, abundant dolonoldic, quartzose and drusy. Quartz

-..subhedral grains, drusy clusters. Silt-quartz gralins, probahly chemical. in origin.

Dolomite-- medium fine, lizht gray and fine, dark gray. Chort-some srayish white, fine

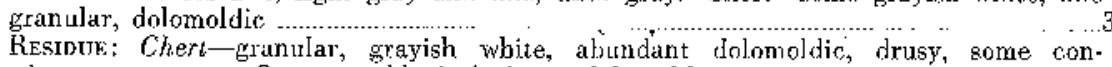
cretionary structure. Quartz-subhedral, drusy, dolomoldic.

Dolomite---medium fine, gray. Chert-somo gray granular

Resibue: Chert-finely granular, abundant to skeletal dolomoldie; granular, light brown, oolitic, smooth, white. Quariz-coarse, subhedral grains and drusy clusters.

Dolomite-fine to medium fine. Chert-small anount gray, granular .........

Residts: Chert-fine granular, buff stained, skeletal dolomoldic; fine granular, grayish, smooth, white. Quartz-subhedral grátins and drusy.

Dolomite fine, gray. Chert ... neall amount granular while, in part dolomitic

Residne; Chert-very fine granular, grayish white, ahundant to skcletal dolomoltic, quartzose and drusy in part; smooth, white Quartz-suljhedral grains and drute.

Dolomite-fine to medium fine, yray

Kessone: Chert-granular, slightly translucent-srayish, scattered to abundant dolomo]. dic, slightly drusy. Quartz-snbhedral srrains, few drusy clusters.

Dolomitc-medium finc, gray to buff-gray. Chert-small amount fine granular, light

Residue: Chert-granular, grayish, in part pseude-oolitic, part quartzose, silightly

drusy: Quartz-smali amonnt subhedral errains and druse.

Dolomile-medium fine, gray and dark gray....

Resious: Chert-fine tratular, grayish; smoolh, white, chalky, hard and rongh; smooth, hiff stained, skeletal dolomoldic. Quartz--anhedral, granular, coarsely drusy; subhedral grains and druse. 
Dolomitc-fine, buff-gray and gray.

Resious: Chert-granular, white, dolomoldic, quartzose, and drusy. Quartz - subhedral grains and drusy clusters.

Dolomite - fine to very fine, krown. Chert-small amount granulgr, grayish, pseudo-

Rolitic: .... Chert-fine granular, grayish, slightly translucent, in part volitic and

Reswue: Chert-fine granular, grayish, slightly translucent, in part volitic and
pseudo-oolitic, and in part drusy, with scattered dolomolds; smooth, grayish white. Quartz - subhedral grains and drusy llakes.

Dolomitc-fine to very fine, gray and buff-gray.

Resivue: Quartz-granular, coarscly drusy, dolomoldic, subbedral grains; very fincly granulated. Chert-tracc gramular, white.

Dolomite-very fine, tray

Restour: Chert--very finely granulated, grayish white. clay-flaky, dolomoldie.

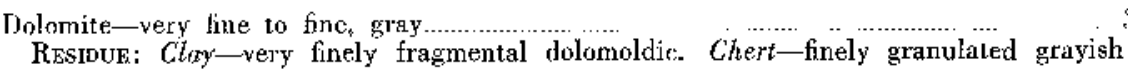
white; trace smooth, white.

Dolomite- fine to medium finc

Risurve: Chert-wsmonth, white, in part finely dolonoldic; chalky, hard, in part

fincly dolonoldic, small amount fine granular quartzose. Quartz--few subbcdral. grains and dusy llakes.

Dolomite-very fine, gray. Chert-small amount granular, grayish.

ResLDU: Chert omooth, grayish, slightily chalcedonic, in part quartzose; fine granular, grayish, in part pseudo-oolitic. Quartz-few subhedrul grains and granulated, dolomoldic fragments. Clay--small amount spongc-like, dolomoldic.

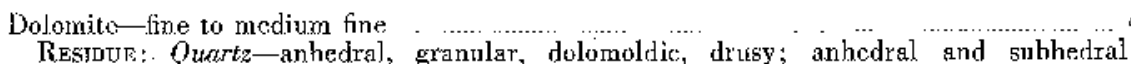
grains, Chert-fine granular, while, skeletal dolomoldic; small amount chalky. Claysmall imount sponge-like, dolomoldic. Spreules -extremely fine, needle-like.

Dolemite-fine and medium fine, buff anc gray .

Risinte: Chert - fine granular, white and buff, drusy, skeletal dolomoldic. Quartzdrusy, dolomoldic: flakes, subhedral grains and granules.

Dolomite -meditern, gray and slightly buft-gray

Risibue: Chert granular, skcletal dolomoldic, white and buf, quartzose and finely

drusy. Quartz-drusy clusters, subhedral and an hedral grains, fine granules.

Dolomite--..very fine, light butl and medium fine, light gray

Ressove; Chert very fine sramular, buft to white, ske]etal dolomoldic; finely granu-

Iated, grayish. white. Quartz-diusy, dolomoldic, subhedral grains.

Dolonite-very fine, buff, some gray....

Resijur: Chert-finely granulated, grayish whitc; trace smooth, white, psendo-oolitic.

Claty-llaky, gray, and skelctal dolomoldic, huff.

Dolomite-very fine to fine, bull-gray

Rrsints: Chert-. finely granulated, whitc, many of the gran illes rhombic, indicating chert replacement of dolomite; smoolh, white grading to hard, chalky. Quartz - lew subhedral. grains, trace fine granular, lacy.

Dolomite-medium to medium fine, light gray

Risidive: Chert-very fine granular, brown and grayish, skcletal dolomoldic, smooth,

brown and white, abuntant dolomoldic. Quartz-silt-size granules, few subhetral. grains. ।

Dolomite-..very fine to medium fine, but and gray

Risinue: Chert-smooth, brown, yery fine, scattered dolomolds; very fine uranular, whitc and buff, partly dolomoldic, very finely granulated. Quartz-very finely granulated, subhedral grains, and fow fincly drusy flakcs.

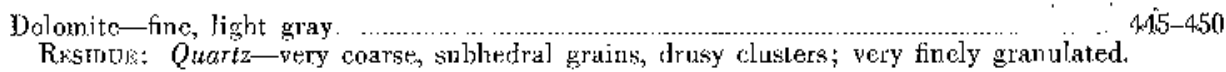

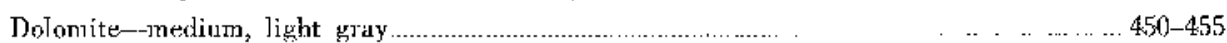

Resious: Chert-chalky, soft, in part dolomoldic. Qusrtz-subhedral grains and small, " dolomoldic, drusy fragments.

Dolomite-medium, lisht srray, sightly porous

Residue: Chett-very fine grained, skeletal dolomoldic, drusy, buf stained. Quartzsubhedral, few anhedral grains, drusy clusters. 


\section{Tanyard Section, Buinet County, Texas}

Feet

below top

Tanyard formation, Stacndebach member, 0-336 feet-

Limestone- extremely fine, dove-gray. Chert-trace granular, white, oolitic

Resinue: Chert - smooth, white, with scattered ooliths; some very fine granular, grayish

chert; slightly quartzose, Quartz-few banded, drusy frigments, subhedral grains.

Limestone-extremcly fine, dove-griy.......

RESIDUE: Clay-sponge-like and flaky, white and maroon.

Limestone-cxtremely fine, very light gray

Residus: Chert-chalky, white, brittle. Clay-flaky, white.

Dolomite-coarse, light gray, with maroon coloration, 60 percent. Limestone-cxtremely

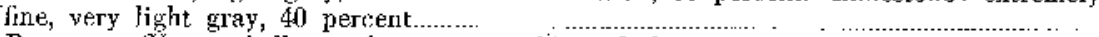

Resinus: Chert chalky, soft, porous, white, slight maroon coloration. Clay-flaky, white and maroon.

Dolomitc-coasse, light gray

Kosidue: Clay-finely fragmental dolomoldic and faky, white and maroon.

Dolomite-coarse to very coarse, light gray

Residue: Clay--laky, porous, and fmely fragmental dolomoldic, white, gray, and maroon.

Dolomite-coarse to very coarse, light gray

Restoue: Clay-flaky and finely Iragmental dolomoldic, white, gray, and mamon.

Dolomite-yery conrse, ligrht gray, in part maroon staincd.

Resrbus: Chay-small amount faky and finely fragmental dolomoldic, maroon and white.

Dolomite-medium coarse, light gray, with maroon staining..

Resinte: Chert-granular, gray to grayish white, quartzose in part. Quartz-smill amount fincly drusy. Clay sponge-like and flaky, white.

Dolonite-medium to coarse, light gray .................
Rr.sinue: Clay--very small amount sponge-like, grayish.

Dolonite-medium coarse to coarsc, light pinkish gray

REsioun: Chert-very fine granular, white, aljundant dolomoldic. Chay- small amount sponge-like, dolomoldic, and flaky.

' Dolomite-course, light gray, in part slightly pinkish.

Resibus: Chert-very fine granular to slightly chalky, white, skcletal dolomoldic.

Quartz-subhedral grains. Clay-finely fragmental, skeletal dolonoldic.

Dolomite-coarse, in part pinkish, light gray..

Resintse: Quartz-fine to coarse, subhedral grains, and dolomoldic, drusy clusters

Clay-w-whitc and maronn, finely fratruental dolomoldic.

Dolomite-methin coarse to coarse, some fine, pinkish and light gray...

Resiove: Clay small amount, white, some maroon, finely fragmental dolomoldic.

Chert-trace soft chalky.

Dolomite-coarse, light gray, and slightly pinkish

R.Esive: Chert-very fine granular, some smooth, white, fincly drusy, sparingly dolomoldic. Quartz-very fine to medium, subhedral grains, drusy clusters. Clay sponge-like and finely fragmental dolomoldic, graly to white.

Dolomitc-fine to nedium fine, ]ight gray, some pink

RrSWUE: Chert-very fine granular, scattercd to abundant dolomoldic, white, some maroon. Quartz-highly drusy, dolomoldic flakes and fragments; fine to very coarse, subhedral grains.

Dolonite-medium, light gray with pinkish streaks

Resibue: Quartz--anhedral, slightly drusy; fine, angular and subhedral grains, Clayvery smali amount fragmental dolomoldic.

Dolomitc-medium fine to medium, gray.

REsidue: Chert-chalky, soft, white, skelctal dolomoldic; irace smooth, white: Claywhite, finely fragmonta] dolomoldic. Spicules-few extremely fine, neadle-like.

Dolomito-medium to modium fine, light gray, slightly pinkish gray and gray.

Residut: Clay-very small amount sponge-Jike and finely fragmental dolomoldic.

Spicule-long, needle-like.

Dolomite-medium fine to medium, gray.

Kessue: Chtrt-very fine granular, gray, scattered to abundant dolomoldic; chalky, white, abundant to skeletal dolomoldic; chalcedonic, in part drusy. Clay-white, finely fragmental, dolomoldic. Quartz-drusy fragment, subhedral grains.
$0-5$ 
Dolomite-coarse, light gray mental.

Dolomite-coarse, some medium fine, pinkish gray.

Restdue: Clay-small amount sponge-like, flaky, white.

Dolomite-coarse, light gray, some pinkish gray. Resinue: Chert-chalky, grayish white to white, skeletal dolomoldic; smooth, white,
keletal dolomoldic; fine granular, white, drusy, in part dolomoldic. Quartz-anhedral, granular, finely drusy, subhedral grains. Clay-white, finely fragmental dolomoldic.

Dolomite-medium, light gray.

Rusidue: Chert-very fine granular, white, skcletal dolomoldic, in part finely drusy; chalky, grayish, skelctal dolomoldic. Quartz--very fine, subhedraI grains. Clay-white, finely fragmental dolomoldic.

Dolomite-medium to coarse, light and pinkish gray

RESIDUE: Chert smooth, white to pinkish, very finely drusy, skeletal dolomoldic. Quartz-very fnely drusy fragments. Clay-white, finely fragmental dolomoldic.

Dolomitc-course, light gray.....

REsmue: Chert-smooth, white, abundant to skeletal dolomoldic; finely sranular, white to buff, in part quartzose and finely drusy, skeletal dolomoldis: Quartz-few finely drusy flakes. Clay-white, finely fragmental dolomoldic:

Dolomite-medium coarse, light gray.......

Resinue: Chert-fine granular, white, quartzose and fincly drusy, skeletal dolomoldic; smooth, white, skeletal dolomoldic. Quartz-anhedral, granulir, drusy, dolomoldic, very fine, angular to medium, subhedral grains. Clay-white, finely fragmental, dolomoldic. Silt-clear quatt, probably chemical in origin.

Dolomite-medium coarse, light gray

ResuDU:: Quartz--fine to very coarse, subhedral grains, few drusy clusters, Chert -..very fine granı]ar, white, abundant to skeletal dolomoldic, quartzose and drusy. Clayvery finely Iragmental, dolomoldic, white and pink.

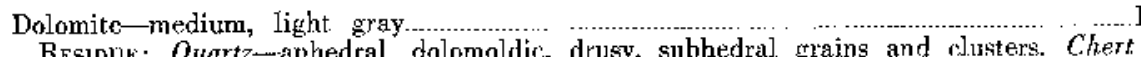
REsidve: Quartz-anhedral, dolomoldic, drusy, subhedral, chalky, dolomoldic. Clay-cream and white, very finely fragmental dolomoldic.

Dolomite-medium, light gray and fine, buff-gray, 90 percent. Chert-very fine granular,

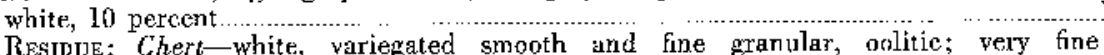
RASIDJE: Chert-white, variegated smooth and fine granular, oolitic; very fine
ranular, cream-white, abundant to skelctal dolomoldic; drusy in part. Quartz--fine to coarse, subhedral grisins, drusy clusters. Clay-fincly fragmental dolomoldic, white.

Dolomite-- fine to medium tray, in part slightly juinkish

Pisinus: Chert-very fine granular, whitc and pink, drusy, abundant to skeletal dolomoldic. Quartz- ine to very coarse, subhedral grains, drusy clusters. Clay-awhite, finely Iragmental dolomoldic.

Dolomite-wime to medium, gray.

REstDtil: Quartz-fine to coursely drusy fragments; fine to vory coarse, subhedral grains. Chert-fine granular, grayish white, scattered to abundant dolomoldic.

Dolomite-modium fine to medium. gray...

- Rrsidue: Quartz-drisy flakes and fragments, in part dolomoldic; fine to coarse, subhedral grains. Clay-white and maroon flecked, skeletal dolomoldic.

Dolomite-medium, gray and fine, buff.cray...

Fieswov: Chert-fine granular, white, some pink, abundant to scattered dolomoldic.

Quartz - small amount funely drusy. Clay-white, finely fragmental dolomoldic.

Dolomite-medium to fine, gray.

Resinus: Chert-fine granular, white, quartzose and drusy, abundant dolomoldic:

Quartz-very fine to coarse, subhedral grains.

Dolomite-medium fine, buI-gray..... .

ResinIe: Chert-very fine granular, grayish white, partly quartzose and drusy, abundant

dolomoldic. Quartz-very fine to medium, stbbhedral grains.

Dolomite medium to medium coarse, light gray

Residive: Clay mall amount, grayish, finely fragmental dolomolfic.

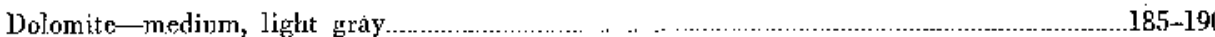

Restoue: Clay-sma]I amount sponge-like, gray and white, finely fragmental doTomoldic. 
Dolomite-medium to fine, light gray, 90 percent. Chert-fine granular, white, 10 percent

Resivite: Chert-granular, white, scattered dolomoldic. Quartz-very fine to coarse, subhedral grains, drusy, dolomoldic fragments.

Dolonite-fine, slightly pinkish gray, 90 percent. Chert-grayish white, granular, oolitic,

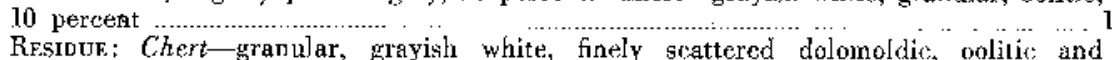
Residue: Chert-granular, grayish white, finely scattered dolomoldic, oolitic: and
pseudo-oolitic, in part quartzose; smooth, white, oolitic. Quartz-very fine to coarse, subhedral grairs.

Dolomite-medium fine, pink, 90 percent. Chert-white, porcelaneous, 10 percent.

Residue: Chert-ordinary smooth and porcelaneous, white; very fine granular, white to pink, scattered dolomoldie. Quartz-fine to coarse, subhedral grains. Clay-sma]T amount white and pink, very fincly fragmental dolomoldie.

Dolomite-medium fine to fine, light gray and pink

Resibue: Quartz-drusy, dolomoldic fragment, and few subhedral grains. Clay-small. amount whitc and pink, finely fragmental and skeletal dolomoldic..

Dolomite-medium fine, gray, some pink staining. Chert-trace white, granular, very

finely oolitic

Rastove: Chert - fine granular, grayish white and pink, in part abundant dolomoldic and quartzose, in part very finely oolitic. Quartz-.-finely drusy flakes, fime angular grains. Clay-small amount white, finely fragmentyl.

Dolomite-fine, gray and pink, 80 percent. Chert-fine graular and porcelaneous,

white, quartzose and drusy in part, 20 percent

Rrsidur: Chert-granular, white to gray, very scattered dolomoldic, in part oolitic, with trace oomolds, in part quartzose and drusy; ordinary and porcelaneous smooth, white to grayish chert. Quartz - anhedral, clear, drusy fragments; fine to very cossse, subhedral grains, Clay- small amount finely fragmental.

Jolomite-fine to medium, slightly pinkish yray.........

Residue: Chert-small amount grayish, finely graunlated. Quartz-few subhedral grains.

Dolomite-medium to medium fine, gray and pinkish.

Residit:: Quartz-fine to coarse, subhedral grains; very finely granulated. Clay-small amount white, finely fragmental dolomoldic.

Dolomite--medium coarse to medium, light gray

REsIDIf: Clay-small amount white, fincly fragmental dolomoldic.

Dolomite-Inedium fine to fine, gray, some ninkish

Residue: Chert-very fine granular, white, abundant to skeletal dolomoldic. Quartz-medium, subhedral grains, very fine, angular granules, few finely drusy flakes. Claywhite, finely fragmental, dolomoldic.

Dolomite-fine to modium line, pinkish gray.

Residue: Chert-grayish, finely granulated, rhombic granules; trace fine granular, white, dolomoldic. Clay-small amount white, finely fragmental dolomoldic.

Dolomite-fine to medium coarse, light gxay.

Reswove: Quartz-finely granulated; trace dolomoldic, finely drusy; few subhedral grains. Clay-white, skeletal dolomoldie.

Dolomite-fine, pinkish gray, some medium, light gray.

Rrsinue: Chert-very fune granular, very finely and abundantly drusy, skeletal dolo. moldic. Quartz-very fine granules and fine subhedral grains.

Dolomite-fine, slightly pinkish, some medium line, light gray

R.ssinue: Chert-fine granular, grayish white, in part very finely drusy, skeletal dolomoldic; smooth, white, skeletal dolonoldic. Quartz - fine to medium, subhodral grains, and finely granulated.

Dolomite-medium fine to coarse, light gray, perous

Resibue: Quartz---very small amount very fine, subhedral grains.

Dolomite--fine, pinkish gray.

Residue: Chert-small amount grayish, finely granular. Quartz-few subhedral graing. Clay - small amount very finely fragmental, dolomoldic.

Dolomite-fine to medium finc, some pinkish... Residue: Chert-granular, white, in part very fnely dolomoldic; chalky, in part very
finely porous and dolomoldic; very fine granules in part thombic. Clay small amount sponge-like, white to buff. 
Dulomite-medium to fine, light gray and pinkish......

Residue: Quartz-subbedral, very fine to very coarse grains. Chert - smooth, tan, and pink, skeletal dolomoldic, in part giartzose and drusy.

Dolomite-medium, light gray and fine, pinkish gray.

Residus: Chert-granular, white, fimely drusy, skeletal dolomoldjc. Quartz-very fine, angular grains.

Dolomite-finc, pinkish, and medium coarse, light sray

Resmue: Chert-granılar, white, highly drusy; skeletal dolomoldic. Quartz-drusy,

dolomoldic flakes and very tinc, sublhedral grains. Clay-gray, flaky, and very finely fragmental dolomoldic.

Dolomite-medium coarse and fine, ninkish uray

Resrous: Chert-small amount fine granular, white and pinkish, dolomoldic. Claysmall amount sponge-like, very fincly fragmental and dolomoldic

Dolomite-medium to coarse, light gray, some pinkish

Resinuk: Chert-small amount brittle, chalky. Clay-gray, Iragmental dolomoldic.

Dolomite-fine, gray, in part pinkish

Resinue: Clay s small amount white, gray, pink, finely lragmental dolomoldie. Quartz - trace fincly drusy. Spricules-few very finc, ncedle-like.

Dolomite-fine, buff: gray and pinkish

Resiove: Chert - very fine erranular, white to grayish, some pink, scattered to abundant, finely dolomoldic; smooth, white, with finely dolomoldic contact suríuses; chalky, sliphity dolomoldic. Quortz-small amount dolomoldic, drusy; few subbedral yrains. Clay-white, very finely fragmental dolomo]dic.

Dolomite-medium coarse to medium fine, light gray and pink

Restnits: Chert--fine aranular, white and pink, in part drusy, abundant to skeletal dolomoldic; chalky, small amount dolomoldic. Quartz-dolomoldic, drusy fragments, fine, subhedral grains.

Dolomite-coarse, grayish white

Resiotr: Chert-sranular, white, abundant to skeletal, coarsely dolomoldis, in part drusy. Quartz-fine to coarse subhedral grains, dolomoldic, drusy fragments.

Dolomite-medium to medium fine, light gray, some pink

Resistour: Chert-granular, white, quartzose and finely drusy, skeleta] dolomoldic.

Quartz-finely drasy, dolomoldic, few subhedral grains.

Dolomite-medium to coarse, light gray

Rusinve: Chert-small amount finely granulated. Shale-green to dark green, waxy. Cloy-small amount white, finely fragmental.

Dolomite-coarse, light rray.

Resivue: Shale-smaj] amount light green, some dark green, waxy, in fine fragments.

Chert-trace fincly granulated.

Tanyard formation, Threadgill memher, 336 ..538 leet---.

Dolomite--.coarse to very coarse, light gray, some pinkish

Residue: Shale-dark maroon and dark green, waxy, in part dolomoldic. Clay-small amount sponge-like and finely fragmental dolomoldic, white.

Dolomitc-cosrse, light gray, some buff staining.

Resibue: Shale-green, waxy, in very fine fragments. Chert-small amount soft chilky; trace granulated.

Dolomite---coarse, light gray, some maroon stained

Rrsidive: Shale-light green, some dark green and maroon, waxy. Chert-small amount granulated; trace smooth, lacy.

Dolomite-coarse, light gray, some purplish

Resivue: Shale-waxy, grayish white to purplish and maroon, fragmental skcletal dolomoldic. Clay--small amount flaky. Quarlz-few medium to coarse, subhedral grains.

Dolomite-cossc to very coarse, light gray, some purplish.

Resimul: Chert-small amount finely grannlated. Shale -waxy, greenish and purplish to maroon. Clay-trace flaky.

Dolomite--coarse to modium coarsc, grayish white

Residue: Chert-granulated, white. Shole-small amounl waxy, green and maroon, fragmental dolomoldic.

Dolomite-iorrse, very Jight gray, some slightly pinkish.

Residute; Shale-waxy, green, some maroon, traces of dolomolds. Chert-small amount white, granulated. 
Dolomite-coarse, very light gray....

Resivue: Shale-waxy, drab green, some maroon. Chert-trace granular, dolomoldic.

Dolomite-coarsc, some fine, very light gray, some purplish staining, 60 percent. Ijime-

stone-mextremely fine, grayish white, some purplish staining, 40 percent ................... 375-380

Residue: Shale-small amount waxy, drab green. Cheri-small amount very finely. granulated; trace rough, granular.

Dolomite-coarsc, white, 80 percent. Limestone-extremely line, grayish white, 20 jer-

cent. Chert-trace gray granular.............................................. 380-385

Rrsidus: Chert-uranular, grayish, with granulated surfaces; small amount very

finely granulated. Shale-very smal]. anount green, waxy.

Dolomite-coarse to very coarse, grayish white.

Restoue: Shale - small amount waxy, dark gray, greenish and maroon.

Limestone-extrcmely fine, grayish white. Dolomite-trace white....... . . ........390-395

Resinue: Chert-...gray, granular, in part porous. Shale - small amount waxy, greenish and maroon.

Dolomite-very coarse, white, ,trace pink

Residus: Chert-small amount chalky, roughly nodular, trace of ]acy, Shaletrace greenish, waxy.

Dolomite-very coarse, light gray and pink, 50 percent. Limestone-extromety fine, grayish white, 50 percent.

REsıbue: Chert-granular, gray, slightly translucent. Shale-waxy, gráyish white, dull. green, maroon, and some bright green. Quartz-few fine, euhedral, medium stubby prisms.

Limestone-extremcly fine, slightly grayish white.

RFsidue: Shale-very small amount maroon and greenish gray in very line Iragments. Silt-very small amount silt-sizc rhombs.

Dolomite-very coarse, white. Limestone-small amount extrcmely fine, very light gray, dolomitio and dolomoldic

Residue: Shale-very emall anount waxy, greenish gray, maroon, trace bright green,

in very fine lragments.

Limestone-extremely fine, grayish white, trace dolomitic, trace purplish color

Residue: Shale-small amount waxy, bulf and drab green.

Limestone--extremely fine, white, trace dolomitic

Residue: Chert-granular, semi-transclucent-gray, highly porous to lacy; smooth,

white, roughly concretionary nodules. Shale---very small amount waxy grcen.

Limestone --extremely fine, very light gray, traces dolomilic.

RFsidive; Shale-very small amount waxy, buff-green in extremely fine fragments.

Limestone-extremeJy fine, very light gray; trace finely dolomitic

Resinve: Shale - mall amount waxy, green, sowe maronn.

Iimestone-extremely fire, slightly grayish white, trace dolomitic

Residue: None.

Limestone-extremcly fine, slighlly grayish white, trace dolomitic

Rrstoue: Quartz-anhedral, highly porous to lacy. Chert smooth, white, roughly

nodular. Shale-small amount waxy grecn.

Limestone-extremely fine, slightly grayish while

Residue: Shale-wlew fine, waxy, green flakes.

Limestone-extremely finc, whitc, in part with slightly greenish tint..

$$
\text { Residut: Nonc. }
$$

Limestone-extrenely. fine, slightly grayish. white

Resivue: Chert - small amount smooth, white, finely concretionary. Shale-very small

amount waxy, green.

Limestone-extremely fine, grayish white

Resivue: Chert-trace granular, lacy, and fincly nodular.

Limestone-xtremely finc, grayish white.

Resingti: Cherl - trace nodular, white.

Limestone-extremely finc, light gray, trace coarsely dolomitic.

R.sibrje: Shalc-trace waxy, green. Silt-few rhombic and angular grains.

Limestone--extremely fine, grayish whise

Residue: Shale-trace waxy green. Silt-smal] amount rhombic grains. 
Limestone-.extrencly fine, grayish white, in part with indistinct, finely fragmenta]

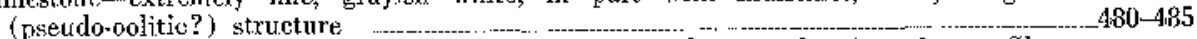
Rrsidne: Quartz-anhedral, in fragments with rough, granulated surfaces. Cherttrace white, rodular, and granular, slightly trans] ucent-grayish.

Limestone-extremely fine, light gray

Rksibtive: Shale-very small amount waxy, drab green. Silt-small amount, rhombic srotins.

Jimestone -extremely fine, grayish white, trace dolomitic:.........

Resiove: Chert-trace, fine granular. Sult-rhombic grains.

Limestone-cxtremely fine, slightly grayish white Restorte: None.

Limestone-extremely fine, slightly grayish white, in part coarsely dolomitic Resibur: Shalc-very smal] amount waxy, green. Silt--irace rhombic grains.

Limestone-..extremely fine, Errayish white, in part slightly dolomitit", with slightly greenish

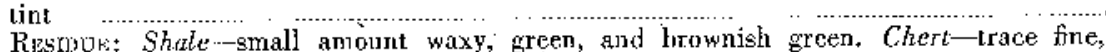
ilicified rhombs. Silt-rhombic grains.

Limestone-extremely fine, grayish whitc, 50 percent. Dolomite-coarse, light gray, 50 percent : 3 halc-trace dark grcen, waxy. Silt-trace rhombic grains.

Dolomite-roarse, light gray Residus: Quartz-anhedral, cloudy, rough to lacy fragments; trace finely granulated. Shale--small amount brownith green, waxy.

Dolomitc-medium. to coarse, gray...

Resulve: Shale--drab green., some maroon, waxy. Silt-very fine, rhombic grains.

I) olomite---. coarse to medium, ]ight graty....

Rasmite: Shale-daxk green, waxy, trace of dolomolds. Quartz-small amount finely granulated.

Dolomile--coarsc, limht gray.

Risidue: Chert-small amount white, srunulatcd, trace white, nodular. Clay-spongelike, in part dolomoldic. Shale-small amount green, waxy, Silt-very fine, in part rhombic grains Quartz- Lrace anhedral, lacy.

Dolomite-medium, light grny, 60 percent. Limestonc-fine, purplish maroon, 40 per-

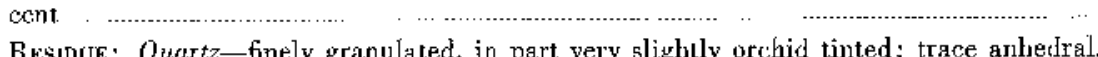
acy. Chent-trace rough, whitc, chalky,

Wilberris formation, $538-570$ leet. -

Dolomite-very fine, dull purplish marvon, sorne buft-gray

Resibue: Chert-very fnely givanulated, slightly purplish tinted. Clay-small amount very finely dolomoldic, while to buff.

Dolomite... very finc, gray, some purplish coloration, in part siliceous.

Restntis: Chert-very fine granular, grayish white to carthy gray, very seattcred to abundant frely dolomoldic; some smooth, white, slightly chalcedonic; trace chalky. Clay-grayish white, mostly extrcmcly fine frogmental. Quartz--small amount drusy.

Dolomite-very tine, buff-gray and slightly purplish, in part siliceous. Chert-sone

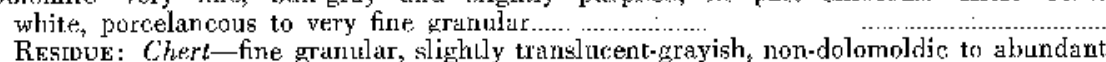
iolomoldic; somo white, porceleneous, some slightly chalcedonic. Clay-grayish white, extremely fine fragmental.

Dolomite-wery fine to extreme]y fine, buff-gray, some purplish, in part silicenus. Chert

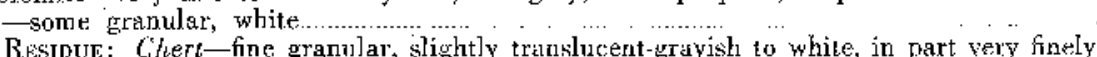
Residue: Cifert-fine granular, slightly tranklucent-yrayish to white, in part very finely
dolomoldic; some buff stained and nurplish, fine granular, Chay-gratyish white, extremely fine fragincntal.

Dolomite--very fine buff-gray, trace purplish. Cherl. some very fine sranular, white . 560-565 Restone: Cthert-very fine granular, buff, pink stained, white, and slightly translucontgrayish, non-dolomoldic to abundant. dolomoldic; some chalky, skeletal dolomoldic: Quartz-some fusely drusy flakes. Clay-grayish white, extremely fine trăgmental.

Dolomite-very fine, buff-gray and purplish gray

Rssmus: Clay-white, some pink, finely fragmental, skeletal dolomoldic. Chert-soft, chalky, scaltered dolomoldic. 



\section{INDEX}

necessory materialk: 21

acestic acid: $8,9,10$

allogenic rçidues: 10

anhydrite: 21

Arbuckle group : 6, 16

Mountaina: ?, 16

Archer County: 15, 16

arcillaceous material : 12,20

Arkansas: 7

authigenic residues: 10

Backbune Mountain section : 9

banded chert: 19

Barnes, V. E.: 7, 14, 16

Beqeh Mountrin: 18

beekite: 2

Blanco County : 17

boundary, Gorman-Honeycut ; 15, 16

Gorman-Tanyard: 15,17

Burnet County : 36

Cambrian age: 16

Central Mixeral region : 7

chalcedonic ehert: 21

chert: $9 ; 12,18-20$

banded : 19

chalcedonie : 21

dolomotrhic: 1

drus, : 19

epigenetic: 10

facy-structured : 19

oolitic: 11,19

comoldie: 19 .

pseudo-oolitie: 19

quartrase: 20

spieular : 20

syngenetic: 10,11

Cherokee Creok section: 9

clastics : $20-21$

fracies : 6

clay $: 20$

Cloud, P, E., Jr. : 7, 14, 16

Colorado: 15

convilonts : 10, 21

Crane County : 17

Crockett County : 18

Crowley, A. J,: is

Daracim No: 1 Seaboard well : If

dolucastic : 19

drolomold : 19

dolumoldic ehert: 19

dolomorphic chert: 19

drusy ehert: 19

Fastland County: 16

Ellenburgér, standitd section of: $\$ 14$ type section of : 14

use of term: 5

El Puso furmation : 6,17

region: 7

epirenetic cherts : 10

residues : 10

arath County: 15, I6)

facies : 8

clastic: 6

unit: 6

Fee No. 4-C Humble well: 18

feldopar: 10, 21

Fisher County : 15,16

fossil Frasments : 21

Gillespie County: 13

slauconite: $10,11,12,21$

Goldieh, S. S.: 21

Gorman Falls section : 14

snmple deseriptiuns: $23-30$

-Trnyserd section: 9 ,

Gorman formation: $6,7,13-14,26-40,31$

residues: 17

-Honeycut boundary : 15,16

-. Tanyard boundary: 15, I7

sross litholoxy : 11
Hrmilton County : 16

Hedrick No. 1 McCirthy well : 1.6

Horeyent formation : $6,7,14,17,18,23-26$ Gorman boundary: 16

residues: 17

Humble No: 4-C l'ee well : 18

hydrochloric acid: $8,9,10$

insoluble rosidues: $8,0-10,11,12,19$

Ireland, H, A. : 18

Johnson. City section: 9, 11

K.indblade formation: 16

K.M.A.-EAlenburyer field : 10

lacy-structured chert: 19

Jampasas County : 23

limonitc: 21

litholuxic luos : 12

lithology, fross: 11

Jinno River section: $9,11,12,13,17$ uplift: 7, 15

logs, hitholostic: 12

resiklue: it

type: 14

MeCarthy No, 1 Hexiriek well : 10

Manitou formation : 6

Marathon formation: 6, 18

resion: 7

uplift: 6, is

Mason Gounty: 18, 17

mica: 10, 21

millerite: 21

Missouri : 7

Moore Hollow-Warren Spring bection : is

oil production: 16, 18

Oklahoma : 6, 7, 10, 15, 16

olite, siliceous: 10

oclith $: 10,19$

silicified: 11

oolitic ehert : 11,19

oumold: 19

oomoldic ehert: 19

Ozark region:?

Fraleonoic formations: 10

Pedernales member: 12, 1 A

potusity : 18

Preston No. 18E Shell weil : 16

pseudomolitic chert: 19

pyrite: ; 10,21

quartz: $9,12,18,20$

yuurtzose chert : 20

residue loys: 12

residues: 18-21

alloreric:

authigenic

epirenetic: 10

Gorman: 17

Homey cilt: 17

insoluble: $8,9-10,11,12$

syngenetis: : 10

sample descriptions, surface sections: 23-41

Forman Fulls section $+23-30$

Spicenwood Creck section : 30-35

Tatnyard section: $86-41$

gand: 12

sandy material: 20

San Sabs Gounty: 7, 23, 30

Seaboard No. I Dawson well : 16

Seaboard

Gorman Falls: 14

Gorman Falla-Tanyard: 1.1

Johnson City : 9, 11

Llano River: $11,12,13,17$

Spicewood Creek: 14

strndird of Fillenturicer: I4

subsurfoce correlation of: 15-18

T'anyard: 14

Threndkill Creek : 12, 13 
type of Ellenburger: 14

Warren Springs-Moure Hollow : 12, 14. shale: 20 .

Shell No. 18E Preston well: 16

biliceous oolite: 10

spicules: 10

silicified coliths: 11

silt : 12

silty material : 20 .

Simpuon formation: 8

Samervell County : 15

Spicewood Creek section: 14

anmple descriptions: $30-35$

spicular ehert: 20

spicules, siliceous: 10

sponge apicules : 21

standard saction of. Fllenhurger: 14

Stacndebach member: $6,7,13,14,31-35,36-39$

Hubsurface sections, correlation of : 15-18

surface samples, preparation of :

surface seclions: $9+10$

Baclibone Mountain : 9

Cherokee Creak : 5

Gorman Falls-Tanyard : 9

Juhnson City : 9

Llano River : 9

sample descriptions: 23-41

Gorman Falls section : 23-30

Spicewrod. Creek saction : $30-35$
Tanyard section : $36-41$

Threadgill Creek: 9

Warren Springs-Meore Hollow:

Byngenetic eherts: 10, 11

residues : I0

Tanyard formation : 7, 8, 12-13, 17, 31-35, 36-41

-Gorman boundkry: 15, 17

residues : 16

geetion: 14

sample deseription: $36-11$

T'aylor County: 16

texture: 18

Threadgill Creek. section: $8,12,13$

l'hrens[gi]l member: $6,7,12,13,14,16,39-41$

Todd field : 18

tripolite: 18

tyje livs: 14

section of Ellenburger: 14

Van Horn regiom: 7, 18

Warren Springs-Movre Hollow section : 9, 12, 14

West. Spring Creek formation: 16

Wiehita County : 10

Mountains: $7,8,15,16$

Wilberns age: 12

dolomites: 11,13

Pormation: $16,17,41$ 

